\title{
"ME CONTA QUAL É A DESSE CONTO": A HISTÓRIA EM QUADRINHO NO ENSINO DE LÍNGUAS
}

\author{
"Tell me what's this tale": comics in the Languages Teaching
}

\author{
Lívia Chaves MELO \\ Universidade Federal do Tocantins \\ liviachavesmelo@hotmail.com
}

\begin{abstract}
RESUMO: Situada na perspectiva indisciplinar da Linguística Aplicada, neste trabalho nosso propósito é discutir o dialogismo de Bakhtin, à luz da teoria de relações dialógicas e vozes verbais, a partir da análise de três personagens principais da História em Quadrinho (HQ) "Me conta qual é a desse conto" da Turma da Mônica. Apresentar ainda uma proposta de atividade didática para aulas de línguas na Educação Básica com base na HQ selecionada. A perspectiva dialógica bakhtiniana é utilizada como principal aporte teórico-metodológico. A análise é de natureza descritivo-interpretativa e segue uma abordagem essencialmente qualitativa. Mostramos que o uso de HQ como material pedagógico em contextos de instrução é bastante proveitoso não só por sua ludicidade, mas por seus recursos multimodais, que facilitam e instigam à leitura, estudo dos conteúdos curriculares e à produção escrita. PALAVRAS-CHAVE: Ensino de Línguas; História em Quadrinho; Dialogismo.
\end{abstract}

\begin{abstract}
Within the indisciplinary field of Applied Linguistics, in this research our purpose is to discuss Bakhtin's dialogism in the light of the theory of dialogical relations and verbal voices, based on the analysis of three main characters in the comic "Tell me what's this tale" by Monica and friends. Present a didactic activity proposal for language classes in Basic Education based on the comic selected. Dialogical studies of language according to Bakhtin's perspective is the theoretical apparatus that guided this research. The analysis is descriptive-interpretive and follows an essentially qualitative research approach. We show that the use of comic as teaching material in instructional contexts is so useful not only for its joyful characteristics, but for its multimodal resources, which facilitate and instigate reading, study of curricular contents and written production. KEYWORDS: Languages Teaching; Comics; Dialogism.
\end{abstract}


Nós ficávamos muito, muito caladinhos. É que a gente ficava lendo nossas revistinhas, nossos tico-ticos e gibis - já tinha menino lendo até Tarzan ou O Espirito - além de outras revistas que ela mesma trazia de casa para nos emprestar. Então, de repente, o Padreco batia na porta. Rápido, rápido - sob o comando da professora - a gente dava cambalhotas na carteira para esconder as revistinhas, antes que ele entrasse na sala. Acontece que o Padreco era o professor de catecismo do grupo escolar e havia proibido a leitura de histórias em quadrinhos. Segundo o Padreco, gibi era pecado! (ZIRALDO, 2012, p. 43-46).

\section{INTRODUÇÃO}

Situada na perspectiva indisciplinar da Linguística Aplicada, campo do conhecimento que problematiza questões sociais envolvendo o uso da linguagem, nas mais diversas atividades do fazer humano e que vê a produção de material didático para o ensino de línguas como uma área de atuação, neste trabalho, analisamos a História em Quadrinho (doravante HQ) "Me conta qual é a desse conto" da Turma da Mônica, selecionada por estabelecer relações dialógicas com releituras de contos de fadas. Nosso propósito é discutir o dialogismo de Bakhtin, à luz da teoria de relações dialógicas e vozes verbais, a partir da análise de três personagens principais do texto em questão: Magali, Quinzinho e Mingau. Apresentar ainda uma proposta de atividade didática para aulas de línguas na Educação Básica com base na HQ selecionada.

Ao considerar a epígrafe ${ }^{1}$ deste texto, pertencente a obra "Uma professora muito maluquinha", escrita por Ziraldo ${ }^{2}$ (2012), identificamos na narrativa as estratégias pedagógicas que uma alfabetizadora utilizava para estimular e ensinar seus alunos a aprender a aprender, possibilitando-lhes desenvolver o gosto pela leitura, escrita, matemática, história e as demais matérias do currículo escolar através de uma variedade

\footnotetext{
${ }^{1}$ A epígrafe refere-se a uma ocasião em que a professora levou para a sala de aula os gibis "O Tico-Tico", uma das primeiras revistas a publicar HQ no Brasil, lançada no dia 11 de outubro de 1905 pela editora O Malho; "O Espírito", revista que publicava as histórias policiais de um herói mascarado, criado pelo desenhista norte americano Will Eisner; além de "Tarzan", entre outras que eram sucesso nas décadas de 1940. Conforme observável na epígrafe deste texto, sob a orientação da professora maluquinha, os alunos da narrativa em destaque liam as revistas escondidos do Padreco e ficavam encantados.

${ }^{2}$ Ziraldo Alves Pinto foi pioneiro das revistas em quadrinhos feitas por um só autor no Brasil. O cartunista é autor de diversas obras e personagens conhecidos. Tornou-se um dos maiores escritores da literatura infantil do país.
} 
de gêneros discursivos, dentre os quais estavam as HQ. Infelizmente, tanto no Brasil como em vários outros países, durante muito tempo, as HQ foram consideradas por padres, pais e educadores como uma ameaça ao desenvolvimento intelectual de crianças e jovens. Achavam que as leituras incitavam à violência e eram vistas como criações diabólicas. Por isso, era algo inaceitável para a sala de aula. Aqueles que insistiam nas leituras, as liam escondidas e, caso fossem flagrados, seriam rigorosamente repreendidos (cf. MOYA, 1993). A entrada das HQ no ambiente escolar encontrou severas restrições.

No entanto, com o reconhecimento dos benefícios de se inserir as HQ como recurso pedagógico no processo de ensino e aprendizagem, esse gênero tornou-se bemvindo nas escolas e incluído nos livros didáticos de diversas disciplinas no início dos anos noventa (MENDONÇA, 2002).

Inclusive, há estímulo governamental para o seu emprego no currículo escolar, sinalizado pela Lei de Diretrizes e Bases da Educação - LDB (Lei n. 9.394/96, cf. art. $3^{\circ}$, II parágrafo) e oficializado pelos Parâmetros Curriculares Nacionais - PCN (BRASIL, 1998) e, mais recentemente, pela Base Nacional Comum Curricular - BNCC (BRASIL, 2017). A boa aceitação entre os alunos fez com que as HQ fossem incluídas desde 2006 na lista do Programa Nacional Biblioteca da Escola - PNBE (BRASIL, 2002). E, ainda, são contempladas em provas oficiais, como o Exame Nacional do Ensino Médio - ENEM (cf. BARBOSA; RAMOS et al., 2016; RAMOS, 2016; CARVALHO; RIBEIRO, 2018). Entretanto, na maioria das vezes, a utilização dessa produção artística e educativa na escola, não contempla seus aspectos discursivos e gráficos, limita-se aos exercícios de metalinguagem.

Os rudimentos das HQ estão nos primórdios de nossa civilização, quando o homem começou a rabiscar nas paredes das cavernas. Os rabiscos eram feitos inicialmente de forma rústica com pedras e, posteriormente, de forma mais elaborada, com tintas retiradas de plantas. Um pouco mais à frente na história das civilizações, temos os egípcios que ilustravam as paredes de seus templos com episódios de caça, reuniões, oferendas e outras atividades desenvolvidas pelo povo da época de maneira mais elaborada que os homens da caverna, com pigmentos sintéticos e orgânicos. Já nas civilizações grega e romana, a arte sequencial era produzida principalmente em vasos, colunas e em baixos relevos, retratando temas cotidianos, mitológicos ou eróticos. É possível também encontrar a arte sequencial nas representações pictográficas do povo maia, em meados do século $\mathrm{V}$ a.C. que tratavam de representações de seu cotidiano, rituais e crenças astrológicas feitas em papel americano e tinta extraída de casca de árvores (cf. CARVALHO; RIBEIRO, 2018).

No ano de 1827, o artista suíço Rudolphe Töpffer criou "M. Vieux-Bois", 
considerado por diversos estudiosos como a primeira HQ do mundo. A obra apresentava quadrinização, fala direcionada para os personagens e algumas metáforas visuais. Outro precursor dos quadrinhos é o alemão Wilhelm Busch, que em 1865, criou "Max und Moritz / Juca e Chico". Os quadrinhos apresentavam bastante violência em seus desenhos, com personagens travessos, por isso, não foram bem vistos por pais e professores. Angelo Agostini, italiano radicado no Brasil, também é outro precursor dos quadrinhos. Criou suas primeiras histórias ilustradas em 1867, “As Cobranças”. Colaborou com a revista $\mathrm{O}$ Tico-Tico da editora $\mathrm{O}$ Malho, marco inicial das publicações dedicadas às crianças no Brasil. Infelizmente, o pioneirismo de Angelo Agostini é pouco reconhecido dentro e fora do Brasil. Já no ano de 1895 foi publicada a tirinha "Yellow Kid" de Richard F. Outcault considerada a primeira história em quadrinhos continuada com personagem semanal, aos domingos, e em cores, publicada no Sunday New York Journal (cf. MOYA, 1996).

Contudo, foi com a invenção da imprensa por Gutemberg que as imagens gráficas foram conhecidas no mundo. A evolução da indústria tipográfica, o surgimento dos grandes jornais impressos, facilitaram o aparecimento das HQ como meios de comunicação de massa. A consolidação dos principais cartunistas do Brasil ocorreu somente nos anos 50 e 60. Entre os nomes mais reconhecidos destacam-se Ziraldo e Maurício de Sousa. Esse último, foi o idealizador da Turma da Mônica.

Este texto está organizado em quatro principais seções, além desta Introdução, das Considerações finais, Referências e Anexos. A seção denominada Perspectiva teórica concerne aos aportes teóricos e metodológicos utilizados. Na seção Personagens $e$ descrição da HQ selecionada, apresentamos os principais personagens da narrativa e uma das possibilidades de interpretação para a HQ "Me conta qual é a desse conto". Na seção Relações dialógicas e vozes constituintes da $H Q$ analisamos as relações dialógicas e vozes verbais, constituintes do dialogismo do texto em questão. Na seção Questões de compreensão, apresentamos uma proposta de atividade didática para aulas de línguas na Educação Básica com base na HQ selecionada.

\section{PERSPECTIVA TEÓRICA}

A comunicação e interação na sociedade é organizada e significada por meio dos gêneros do discurso. De acordo com o teórico russo Mikhail Bakhtin, gêneros do discurso são determinados "tipos relativamente estáveis de enunciados" que têm uma estrutura constituída por conteúdo temático, estilo verbal e construção composicional (BAKHTIN, 2003, p. 262). 
O conteúdo temático é mais do que o assunto ou tópico principal de um texto. É o conteúdo inferido com base na apreciação de valor, no acento valorativo dado pelo locutor. $\mathrm{O}$ estilo verbal refere-se às escolhas linguísticas que fazemos para dizer o que queremos dizer, para gerar o sentido desejado. Essas escolhas podem estar relacionadas a seleção dos recursos lexicais, fraseológicos e gramaticais da língua. Por sua vez, a construção composicional é a organização e o acabamento geral do gênero como um todo. Liga-se à macroestrutura textual, à progressão temática, à coesão e coerência do texto (cf. BAKHTIN, 2003, ROJO; BARBOSA, 2015).

Embora o ensaio "Os gêneros do discurso" (BAKHTIN, 2003), incluído na coletânea "Estética da criação verbal", seja um dos trabalhos mais difundidos sobre gêneros do discurso, ele não é o único a tratar da questão ${ }^{3}$. A noção geral de gêneros permeia todos os trabalhos de Bakhtin e dos membros de seu Círculo. Na citação clássica sobre a definição, o teórico afirma:

O emprego da língua efetua-se em forma de enunciados (orais e escritos) concretos e únicos, proferidos pelos integrantes desse ou daquele campo da atividade humana. Esses enunciados refletem as condições específicas e as finalidades de cada referido campo não só por seu conteúdo (temático) e pelo estilo da linguagem, ou seja, pela seleção dos recursos lexicais, fraseológicos e gramaticais da língua mas, acima de tudo, por sua construção composicional. Todos estes três elementos - o conteúdo temático, o estilo, a construção composicional - estão indissoluvelmente ligados no todo do enunciado e são igualmente determinados pelas especificidades de um terminado campo da comunicação. Evidentemente, cada enunciado particular é individual, mas cada campo de utilização da língua elabora seus tipos relativamente estáveis de enunciados, os quais denominamos gêneros do discurso (BAKHTIN, 2003, p. 261-262).

Esses três elementos constitutivos dos gêneros, o conteúdo temático, o estilo verbal e a construção composicional, se influenciam e se constituem conjuntamente. São indissociáveis uns dos outros no todo do enunciado. Além disso, são embasados por relações dialógicas.

Bakhtin classifica as formas típicas da comunicação discursiva, isto é, os gêneros

\footnotetext{
${ }^{3}$ Para não reduzirmos o conceito de gêneros do discursivo aos três elementos que o constituem (conteúdo temático, estilo verbal e construção composicional), sugerimos a leitura de Brait e Pistori (2012). No estudo, as autoras expandem suas leituras para além do texto "Os gêneros do discurso" e percorrem outras obras que tratam da questão, para mostrar como o conceito vai se construindo em cada trabalho de Bakhtin e dos membros de seu Círculo.
} 
do discurso, em primários (simples) e secundários (complexos). Os primários são aqueles que decorrem de relações mais casuais, aos encontros do cotidiano, constituídos na comunicação discursiva imediata. São predominantemente, mas não unicamente, na modalidade oral do discurso. Os secundários, por sua vez, decorrerem de relações mais formalizadas e organizadas. São predominantemente, embora não exclusivamente, escritos. No processo de sua formação, os gêneros secundários são integrados pelos primários (BAKHTIN, 2003).

Para conceber gêneros do discurso é necessário ainda considerar as circunstâncias temporais, espaciais e as esferas ideológicas que orientam e constituem o discurso, ou seja, a forma arquitetônica do gênero. Além do mais, as noções de gêneros não se limitam a textos ou aspectos formais da língua por elas mesmas, embora os considere, pois possibilitam a sua existência, têm por base o dialogismo (BRAIT; PISTORI, 2012).

O dialogismo é o princípio básico e nuclear do pensamento bakhtiniano. Constitui o fundamento maior da obra "Problemas da poética de Dostoiévski" e é aqui compreendido como as relações de sentido instituídas entre enunciados concretos de distintos sujeitos na comunicação discursiva. É o modo de funcionamento da linguagem, o princípio constitutivo de todo enunciado (BAKHTIN, 2003, 2013). Nas palavras de Bakhtin:

\begin{abstract}
A orientação dialógica é naturalmente um fenômeno próprio a todo discurso. Trata-se da orientação natural de qualquer discurso vivo. Em todos os seus caminhos até o objeto, em todas as direções, o discurso se encontra com o discurso de outrem e não pode deixar de participar, com ele, de uma interação viva e tensa. Apenas o Adão mítico que chegou com a primeira palavra num mundo virgem, ainda não desacreditado, somente este Adão podia realmente evitar por completo esta mútua orientação dialógica do discurso alheio para o objeto. Para o discurso humano, concreto e histórico, isso não é possível: só em certa medida e convencionalmente é que se pode dele se afastar (BAKHTIN, 2002b, p. 88).
\end{abstract}

No dialogismo, há um vínculo entre palavras alheias e próprias, entre palavras passadas e futuras. Outrossim, não há palavra que seja a primeira ou a última, mas toda palavra enunciada no discurso concreto é plena de palavras dos outros, constituída e articulada pelo já-dito de outros discursos que habitam e entrecruzam o sujeito enunciador. Ainda sobre a concepção de dialogismo, Bakhtin afirma: 
Não existe a primeira nem a última palavra, e não há limites para o contexto dialógico (este se estende ao passado sem limites e ao futuro sem limites). Nem os sentidos do passado, isto é, nascidos do diálogo dos séculos passados, podem jamais ser estáveis (concluídos e acabados de uma vez por todas): eles sempre irão mudar (renovando-se) no processo de desenvolvimento subsequente, futuro, do diálogo. Em qualquer momento do desenvolvimento do diálogo, existem massas imensas e ilimitadas de sentidos esquecidos, mas em determinados momentos do sucessivo desenvolvimento do diálogo, em seu curso, tais sentidos serão relembrados e reviverão em forma renovada (em novo contexto). Não existe nada absolutamente morto: cada sentido terá a sua festa de renovação (BAKHTIN, 2003, p. 410).

No viés bakhtiniano, o dialogismo trata das relações sintáticas de natureza léxicosemânticas instituídas entre os enunciados concretos de distintos sujeitos do discurso. Tais relações ultrapassam os limites da linguística, pois envolvem não só as particularidades lógicas e sintáticas no plano da língua, mas também as influências externas, ou seja, os fatores extralinguísticos da enunciação (cf. BAKHTIN, 2013, p. 209). Algumas dessas relações podem se dar internamente outras externamente ao discurso. Nas representações literárias, por exemplo, especialmente as de caráter narrativo, as relações dialógicas internas ocorrem na interação entre as vozes de personagens e de narrador/autor que organiza e representa esse diálogo. Nessas interações, no interior do texto, é possível simular um confronto dialógico. Sob a orientação dialógica interna, a "minha palavra" encontra na mais íntima relação a palavra alheia sem se fundir a ela, conservando inteiramente a sua autonomia. Já o dialogismo externo são as relações dialógicas de vozes de um enunciado com as vozes exteriores a esse enunciado (cf. BAKHTIN, 2013; MACIEL, 2017). Ecoando Bakhtin (2003, p. 409-410), vê-se, portanto, que "quanto a mim, em tudo eu ouço vozes e relações dialógicas entre elas".

Dialogismo é ainda entendido como as relações estabelecidas entre vozes pertencentes a determinados sujeitos, sejam esses passíveis de identificação ou não. Portanto, falar em dialogismo supõe naturalmente considerar os sujeitos implicados no processo de comunicação, e, nesse sentido, os sujeitos são constituídos e situados no processo sócio-histórico-ideológico em que estão inseridos.

As vozes das quais fala Bakhtin constroem o sentido de nossas enunciações por incitar à resposta e não se trata de emissão vocal. Se identifica com opinião, ponto de vista de sujeitos históricos, postura ideológica e possui sua cronotopia, isto é, sua dimensão espaçotemporal (cf. SIPRIANO; GONÇALVES, 2017). As vozes materializam-se na interação verbal entre os indivíduos socialmente organizados. Assim, os discursos/enunciados são 
permeados por multiplicidade de vozes e estão carregados de intencionalidades, pois toda voz humana envolve relações dialógicas com várias vozes, dado que nenhum sujeito falante é a fonte única de seu próprio discurso. Portanto, todo enunciado é dialógico. Nele, ouve-se sempre a incorporação e a retomada de várias vozes que se entrelaçam em relações de acordos/consensos ou desacordos/dissensos, mesmo que essas vozes não se manifestem no fio do discurso.

A partir da abordagem dialógica da linguagem, assumida neste trabalho, compreendemos as HQ enquanto representantes de gêneros do discurso, as quais constituem gêneros secundários, pois são formas de comunicação cultural e mediação social na forma escrita, materializadas em enunciados reais que, muitas vezes englobam gêneros primários. Em sua estrutura composicional, as HQ são constituídas predominantemente por sequências narrativas justapostas em quadros que combinam a linguagem verbal (narrativa escrita e a falada, colocadas em balões e legendas) e visual (imagem gráfica), por meio das quais o conteúdo temático e o estilo verbal são desenvolvidos.

Na próxima seção, apresentamos a análise da HQ "Me conta qual é a desse conto" da Turma da Mônica, selecionada por estabelecer vínculos dialógicos com narrativas de contos de fadas da literatura clássica infantil, apresentando de modo claro, elos e embates com outras vozes. A análise é de natureza descritivo-interpretativa e segue uma abordagem essencialmente qualitativa. Na HQ em questão, a passagem do estilo do gênero conto para HQ modifica e renova tal gênero.

\section{PERSONAGENS E DESCRIÇÃO DA HQ SELECIONADA}

A leitura apresentada é apenas uma das possibilidades de interpretação da HQ: "Me conta qual é a desse conto" (Turma da Mônica no 27 - Julho/2017) 4 , publicado pela editora Panini. O exemplar do gibi, que é composto pela narrativa em destaque, possui dez HQ no total, contando com o enredo principal e a tira cômica final. No gibi, há também passatempos que juntamente com as $\mathrm{HQ}$, além de entreter, podem ser utilizados como material pedagógico para o ensino de línguas em contextos de instrução. A narrativa é assinada pelo cartunista Maurício de Sousa, um dos mais reconhecidos cartunistas do Brasil, criador da Turma da Mônica, e, na abertura da história, há os nomes do roteirista

\footnotetext{
${ }^{4}$ A HQ foi publicada em Português (Turma da Mônica n ${ }^{\circ} 27$ - Julho/2017), Inglês (Monica and friends - issue 27 - July/2017) e Espanhol (Mónica y sus amigos - número 27 - Julio/2017). A narrativa também está disponível em vídeo no YouTube <https://www.youtube.com/ watch? $=$ bf8foaVr5zs>. Acesso em: 6 jun. 2019.
} 
Rogério Mascarenhas, o desenhista Fernando Luís Campos e arte-final de Reginaldo S. Almeida.

A fim de possibilitar a análise das relações dialógicas e das vozes verbais, constituintes do dialogismo do texto, destacamos, no Quadro 1, as principais características das personagens da HQ, a partir de seus aspectos físicos e psicológicos.

Quadro 1: Principais personagens da HQ "Me conta qual é a desse conto"

Magali é uma das personagens protagonistas das HQ da Turma da
Mônica e é reconhecida por ser amiga de todos, pelo jeito delicado,
sensível, bem-humorado e sempre de bem com a vida, pelo apetite
insaciável e por adorar melancia, a sua fruta predileta. Apesar de ter
um apetite incontrolável, de ser comilona, Magali é magra e um doce
de menina. Essa garota de cabelo escorrido que usa vestido amarelo,
apesar de aparecer com modelos diferentes vez ou outra. Identifica-
se com uma filha de Maurício de Sousa, de mesmo nome. Teve sua
primeira aparição em janeiro de 1963, porém, ganhou sua própria
revista ilustrada em fevereiro de 1989 (cf. SOUSA 2016a; SOUSA,
2017a).




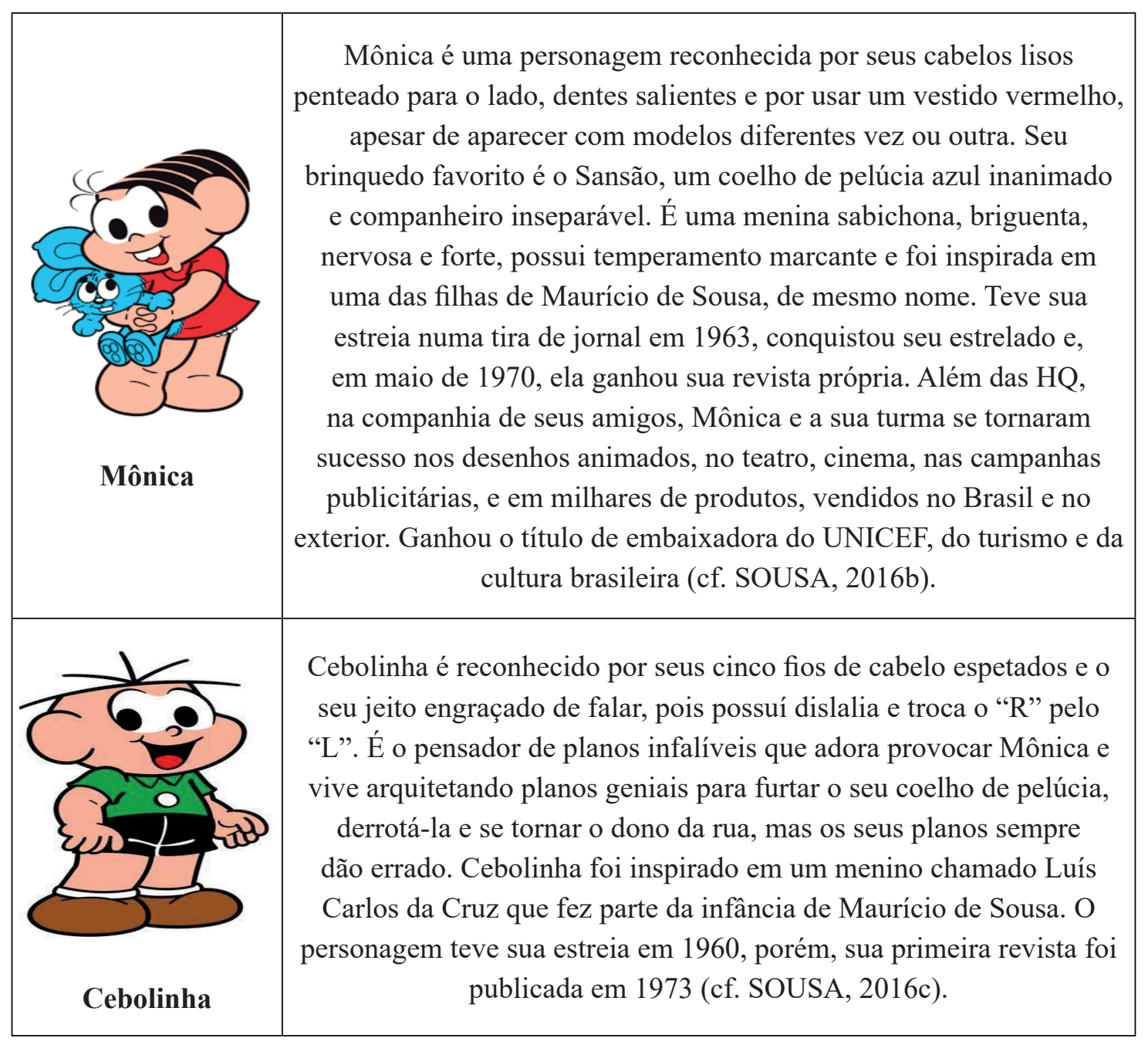

Fonte: A autora.

Disponível em: <http://www.turmadamonica.com.br/>. Acesso em: 6 de jun. 2019.

A HQ "Me conta qual é a desse conto" se inicia com um desentendimento entre Magali e o seu namorado Quinzinho. No enredo, Magali aparece furiosa, contestando com Quinzinho por ser o terceiro encontro que ele se esqueceu de trazer para ela pão de queijo. A garota, intolerante com o namorado, o que é confirmado pelas suas expressões corporais e faciais, afasta-se dele aborrecida.

Quinzinho, incomodado com a atitude de Magali, mostra-se indiferente, como indicam os braços cruzados e a imagem da 'fumaça' sobre sua cabeça indicadora de raiva, afirma que não se liga com o fato de ela ir embora. Ao perceber e questionar a si mesmo sobre a sua insensibilidade com a namorada, o personagem considera-se um monstro por sua atitude e, logo, surge um monstro feroz. 
Para a surpresa de Quinzinho surge também o gato Mingau que se passa por o Gato de Botas dos contos de fadas. Atento aos acontecimentos ao seu redor, cínico e irônico, atitudes expressas em sua face e postura, o gato oferece ajuda a Quinzinho para reconquistar Magali no velho estilo contos de fadas. Desconfiado sobre a eficácia do plano, o garoto é empurrado em direção à namorada.

Disfarçado de uma velha senhora, com uma cesta de maçãs, uma alusão ao conto de fadas Branca de Neve, o gato oferece à Magali uma maçã envenenada e ela o ataca, mordendo a maçã, juntamente com a mão do gato (cf. a onomatopeia que indica o som de uma mordida - NHAC!). Após isso, Magali cai desmaiada. Quinzinho ao vê-la, desesperado, questiona se era isso mesmo que era para acontecer.

$\mathrm{Na}$ sequência, Magali aparece deitada em uma cama desacordada. O gato sugere a Quinzinho, que surge vestido de príncipe nobre, despertar a princesa com um beijo de amor. Temeroso, Quinzinho o questiona sobre tal conduta, já que Magali está inconsciente. Diante disso, o Gato de Botas argumenta que não se fazem mais príncipes como antigamente e o força a beijá-la. Magali desperta sobressaltada e, ao perceber que Quinzinho a beijaria, mesmo estando dormindo, enraivecida, questiona-o sobre o seu comportamento. Muito nervosa, a garota sai caminhando e, Quinzinho, desconcertado, tenta explicar o que estava acontecendo.

Magali é capturada pelo gigante da história João e o pé de feijão. O gato insiste que Quinzinho deve salvá-la. Ao notar que sua opinião não é ouvida, Magali reage com uma mordida em um dos dedos do gigante que perde o equilíbrio e cai no chão. A garota deu-lhe uma lição pela sua falta de educação. Ao perceber que os seus planos não deram certo, o gato, aborrecido, segue com suas artimanhas.

Como no conto de fadas Rapunzel, Magali surge aprisionada no alto de uma torre, sem portas ou escadas, com apenas uma janela no topo. A garota percebeu que o gato estava tramando contra ela. Do lado de fora da torre, havia um dragão assustador. Para salvar a princesa e ganhar o seu coração, o príncipe Quinzinho foi desafiado pelo felino a derrotar o dragão.

Entretanto, de tanto se esforçar para sair das confusões, o estômago de Magali ronca tão alto (ROARC!) e assusta o dragão que foge amedrontado. A garota salta da torre por si mesma e dá uma bronca em Quinzinho e pede a ele que pare de andar com o pessoal de contos de fadas e questiona o fato desse pessoal acreditar que toda mulher deve ser salva por um homem. Ao perceber que fez bobeira, Quinzinho interrompe Magali com um beijo estalado (SMACK!), pede desculpas a ela e diz que não queria brigar. 
Com isso, o Gato de Botas fica chateado, pois Quinzinho não conquistou Magali com nenhuma das travessuras recomendadas por ele, mas sim, pela atitude gentil com a namorada. $\mathrm{O}$ felino questiona a um sapo sobre a validade do beijo e este afirma que foi consentido. O sapo pede um beijo ao gato, prometendo se transformar magicamente em uma princesa.

Enquanto isso, Magali e Quinzinho saem de mãos dadas e apaixonados, assim como revelam, os corações saltando de seus peitos. A garota, delicadamente, convida o amado para comerem pães de queijo e fazerem as pazes. O gato segue com suas invenções, alegando que um Gato de Botas não desiste nunca. No desfecho da narrativa, Cebolinha, que adora provocar Mônica e vive projetando ideias geniais para furtar Sansão, um coelho inanimado de pelúcia azul, surge atrás de um arbusto observando a menina passar com o brinquedo. $\mathrm{O}$ gato aborda o personagem, acreditando que ele deseja conquistar Mônica, oferece ajuda, tentando realizar novas travessuras.

\section{RELAÇÕES DIALÓGICAS E VOZES CONSTITUINTES DA HQ}

AHQ "Me conta qual é a desse conto" carrega uma forte carga dialógica, remetendo ao universo discursivo dos contos de fada, que, por sua vez, resgata outras histórias da literatura clássica infantil. Adiante, destacamos relações dialógicas e vozes verbais que constituem a HQ.

\section{MAGALI: A VOZ DA MULHER INDEPENDENTE}

No quadro adiante, a linguagem verbal (“Ah, parei com você, Quinzinho!” “É o terceiro encontro que você se esquece de trazer o meu pão de queijo!"), juntamente com a linguagem não verbal que compõem sequência narrativa, reforçam a imagem de uma mulher decidida, moderna e independente. A personagem Magali toma a atitude de romper com o relacionamento, isto porque o Quinzinho deixou de agradá-la com os seus pães de queijo. 
Figura 1: Magali enfurecida com Quinzinho

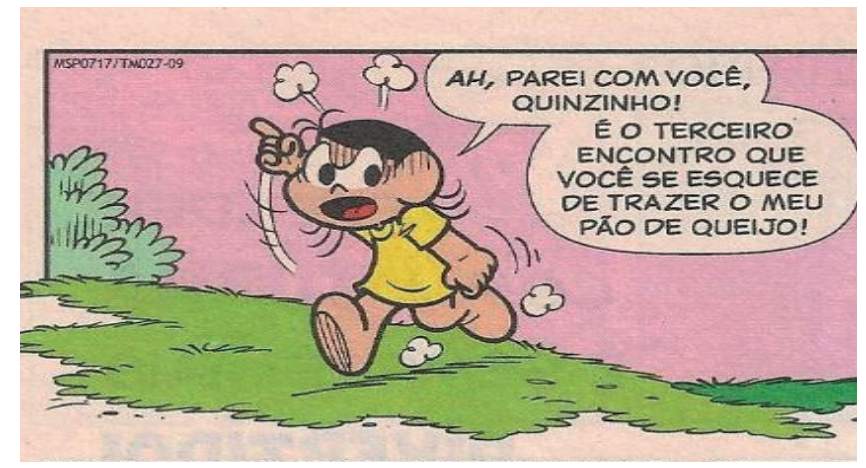

Fonte: Turma da Mônica n 27 - Julho/2017, primeira parte da vinheta 1.

Magali afasta-se de Quinzinho aborrecida como indicam o punho erguido, o dedo indicador apontado para cima, as metáforas visuais (imagem da 'fumaça' acima da cabeça da personagem sinalizando raiva), e as figuras cinéticas (parênteses indicadores de deslocamento físico, linhas que assinalam o espaço percorrido, nuvens próximo aos pés que também indicam movimento, uso dos pontos de exclamação, os quais são recursos semânticos utilizados para expressar indignação da personagem), presentes na primeira vinheta.

Ao final do enredo, é Magali que, delicadamente, toma a atitude de convidar Quinzinho para comer pães de queijo e fazerem as pazes. Ela representa a mulher moderna que possuí papel ativo, demonstrando alguém que está no controle do relacionamento e que decide por sua continuidade: "Oh, Quinzinho!" "Vamos comer uns pães de queijo e fazer as pazes?" (cf. os corações saltando de seus peitos, metáforas visuais presentes na vinheta n. 26). As representações de Magali tida como meiga e um doce de menina (cf. Quadro 1), também veem à tona. 
Figura 2: Magali e Quinzinho fazem as pazes

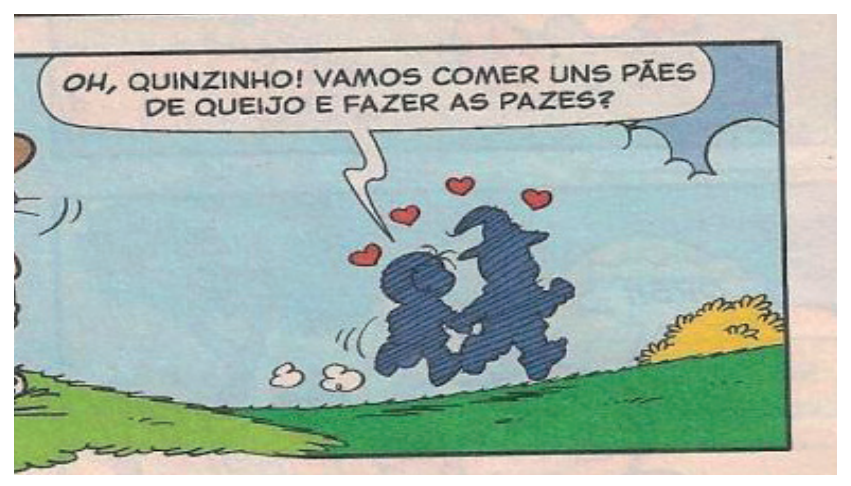

Fonte: Turma da Mônica nº 27 - Julho/2017, segunda parte da vinheta 26.

Nos quadros seguintes, há uma relação de negação entre o papel de Magali e os padrões que se esperam das princesas dos contos de fadas tradicionais. Não é um beijo que a acorda após comer uma maçã envenenada e, sim, a própria Magali ao sentir que alguém irá beijá-la sem o seu consentimento. Não é um príncipe que a salva do castelo do gigante da história João e o pé de feijão, e, sim, ela mesma ao morder o dedo do gigante. Não é um príncipe que a salva da torre do castelo e do dragão, como ocorre em Rapunzel, mas sim, o ronco de seu estômago que faz o dragão ir para bem longe e ela escapa da prisão.

Figura 3: Magali aborrecida com Quinzinho

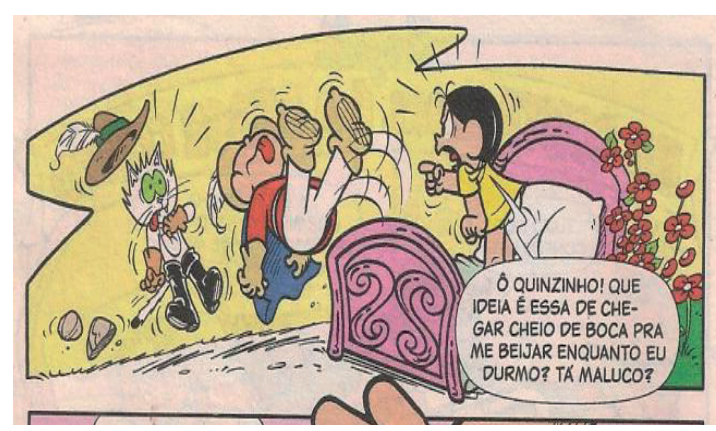

Fonte: Turma da Mônica nº 27 - Julho/2017, vinheta 15 .
Figura 4: Magali brava com o gigante da história João e o pé de feijão

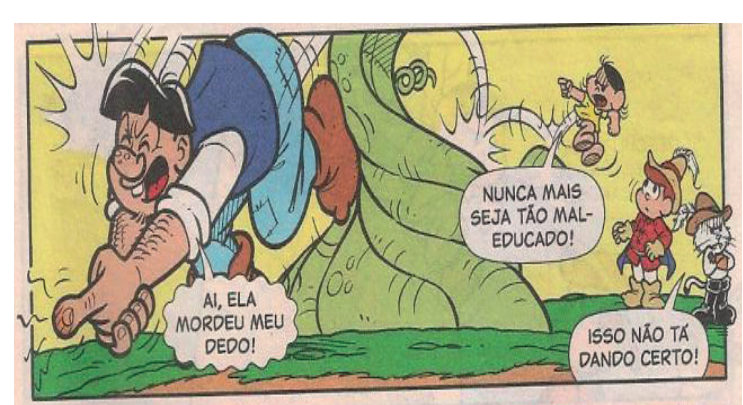

Fonte: Turma da Mônica nº 27 - Julho/2017, vinheta 19 . 
Figura 5: Magali escapa da torre do castelo e do dragão

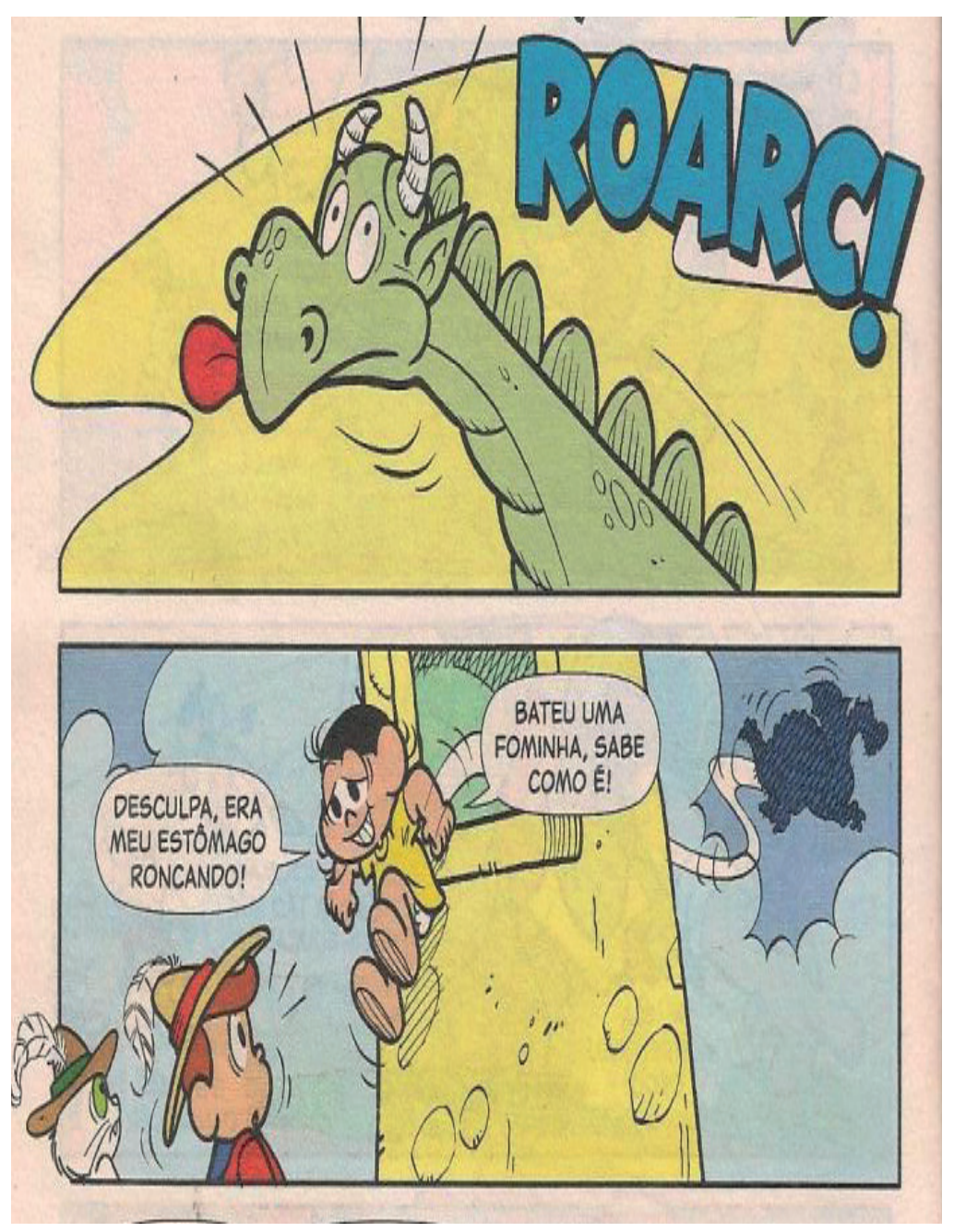

Fonte: Turma da Mônica nº 27 - Julho/2017, vinhetas 22 e 23.

Magali é na verdade, "uma princesa comilona”. Essa representação é reforçada no decorrer de toda a narrativa. Percebe-se o cruzamento das vozes na configuração de Magali que modifica o papel exercido por uma "princesa" dos contos de fada. Nos contos de fadas, apesar de termos personagens malvados, ciumentos, valentes, corajosos, vingativos, as princesas nunca são comilonas.

$\mathrm{Na} \mathrm{HQ}$, Magali é uma garota forte, independente que está constantemente questionando as atitudes que considera injustas. É corajosa e esforça-se para sair de tanta confusão por si mesma, nas aventuras dos contos de fadas, sem a ajuda de um príncipe encantado. Ensina que as mulheres devem pensar por elas mesmas e é tão importante 
quanto um homem, portanto, merecedora da mesma honra e o mesmo respeito.

Figura 6: Magali brava com o gigante da história João e o pé de feijão

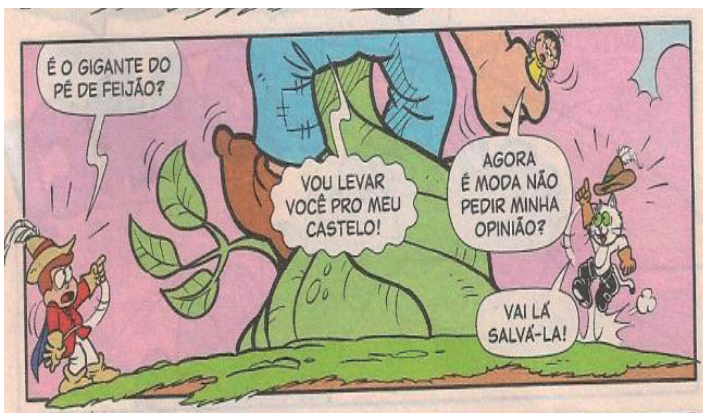

Fonte: Turma da Mônica n 27 - Julho/2017, vinheta 18 .
Figura 7: Magali reclama com Quinzinho

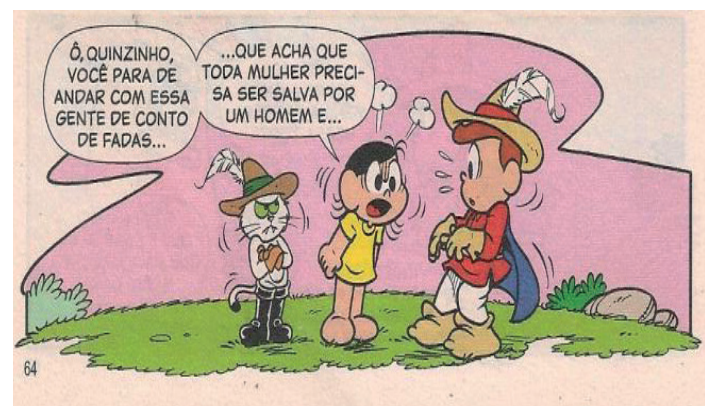

Fonte: Turma da Mônica nº 27 - Julho/2017, vinheta 24 .

$\mathrm{Na} \mathrm{HQ}$, demarca-se relação dialógica a imagem da mulher típica da cultura patriarcal, que é encorajada a se conformar com os estereótipos sexuais, uma donzela em perigo, a espera de um príncipe encantado para ser salva e a ideia de um final feliz estar vinculado à realização do casamento. Além disso, a sua felicidade dependia única e exclusivamente da ação desse príncipe. Em função das novas exigências sociais femininas, a HQ é permeada de ideologias contemporâneas acerca da mulher. Temos a reconstrução da figura da mulher que representa liderança e independência, que conquista o homem, não estando mais presa aos padrões tradicionais de submissão presentes em épocas tradicionais.

\section{QUINZINHO: A VOZ DO HOMEM MODERNO}

A HQ "Me conta qual é a desse conto" se inicia com um desentendimento entre Magali e Quinzinho, que se mostra indiferente à Magali. No quadro adiante, conforme a leitura nos permite compreender, a linguagem verbal ("Vai embora? Não ligo mesmo!"), juntamente com a linguagem não verbal, reforçam o papel do homem indiferente à mulher e seguro de si: o olhar sisudo, os braços cruzados e a imagem da 'fumaça' sobre sua cabeça, reforçam isso. Demarca-se a relação dialógica de concordância com a concepção de homem, presente há séculos na cultura social, estereotipado como grosseiro e forte. 
Figura 8: Quinzinho indiferente à Magali

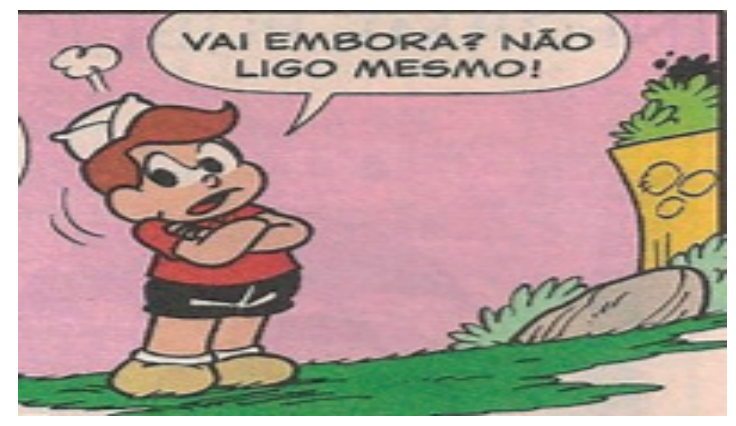

Fonte: Turma da Mônica n 27 - Julho/2017, segunda parte da vinheta 1.

Já no quadro seguinte, essa voz de homem indiferente é revertida em uma voz de fragilidade e reflexão sobre o que fez para a amada.

Figura 9: Quinzinho considera-se um monstro
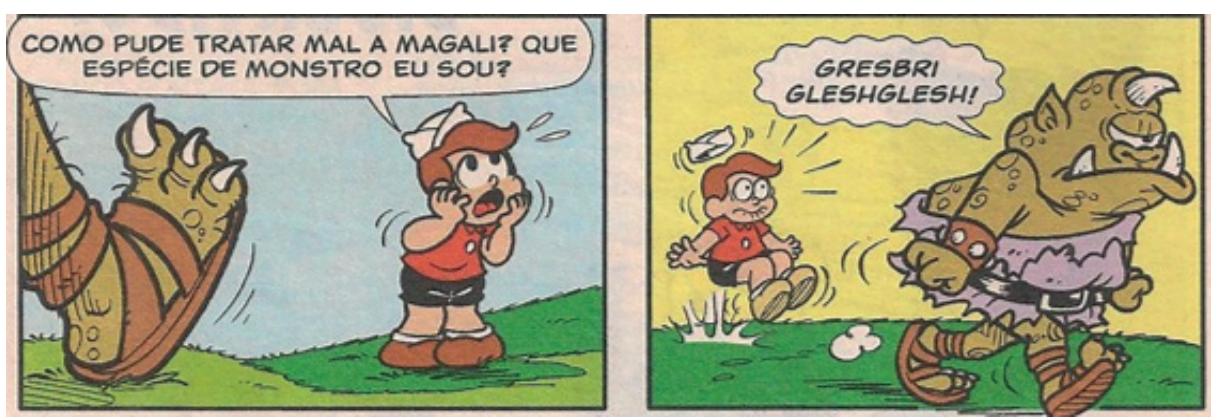

Fonte: Turma da Mônica nº 27 - Julho/2017, vinhetas 2 e 3.

E, assim, o personagem Quinzinho acaba sendo considerado gentil e prestativo (cf. Quadro 1), o que é reforçado no decorrer de toda a narrativa. Ele mesmo percebe que agiu mal com a namorada, considerando-se um "mostro" por sua atitude; o fato de surgir um mostro na história pode reforçar essa ideia e já dar abertura para o desenrolar das ações. O papel de Quinzinho perpassa momentos em que ele apresenta a voz da gentileza e do respeito com a Magali, estabelecendo a concordância com as características dos príncipes de contos de fadas. 
Figura 10: Quinzinho se passa por príncipe

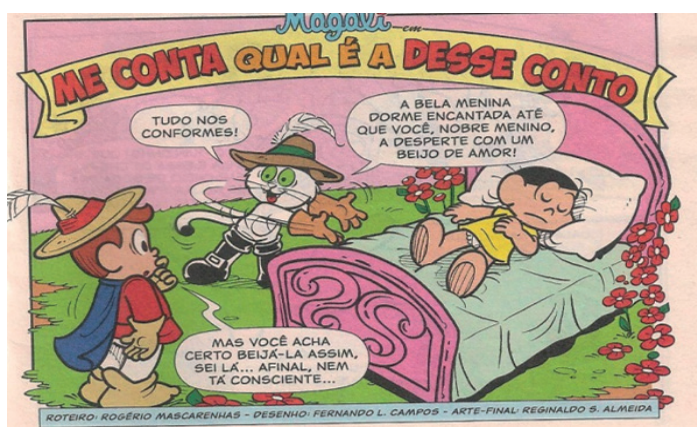

Fonte: Turma da Mônica no 27 - Julho/2017, vinheta 12.
Figura 11: Quinzinho beija Magali

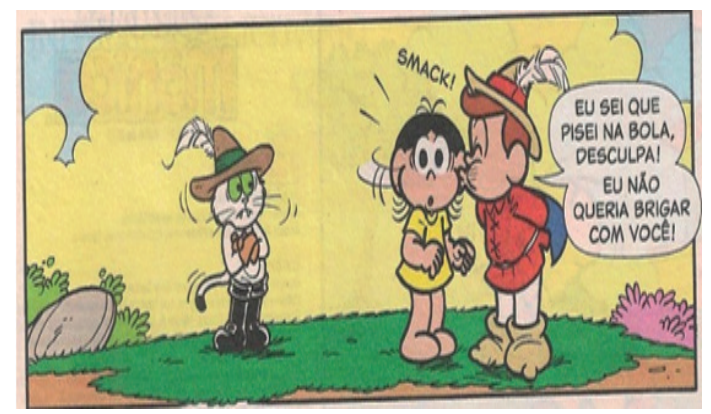

Fonte: Turma da Mônica no 27 - Julho/2017, vinheta 25 .

A voz de Quinzinho, nos quadros reproduzidos, destoa de sua postura rude, demarcando uma postura de fragilidade maior em relação à mulher. Tanto que nos quadros seguintes, ele aparece amedrontado com a possível reação da amada e com outras situações. Nesse ponto, há uma relação de negação entre o papel de Quinzinho e o papel dos clássicos príncipes dos contos de fadas que são destemidos, corajosos e atuam sem pensar na reação da amada.

Figura 12: Quinzinho amedrontado
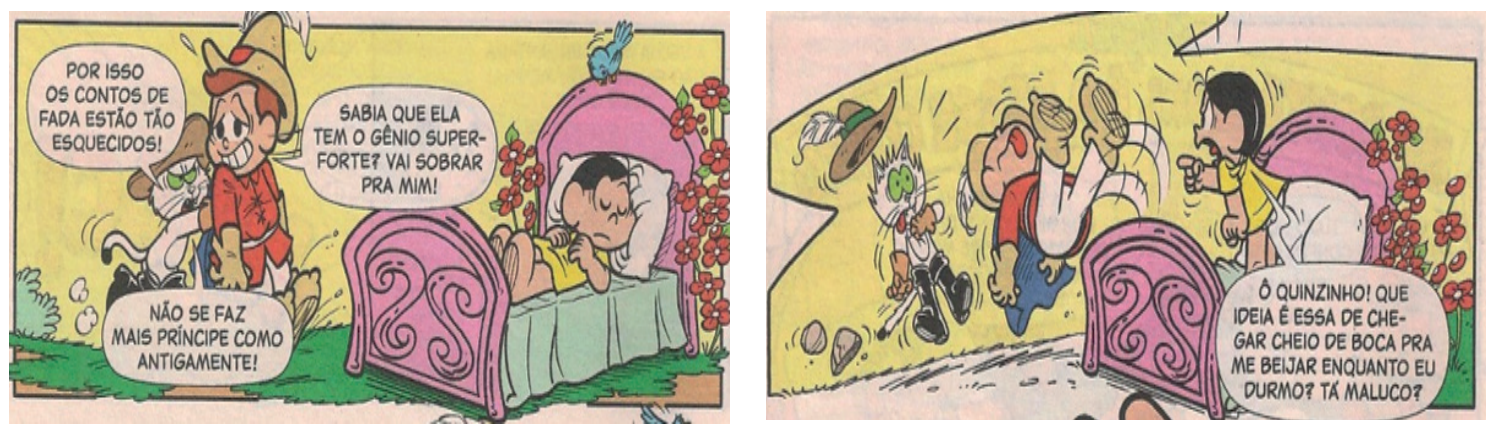

Fonte: Turma da Mônica nº 27 - Julho/2017, vinhetas 13 e 15.

A fala do gato (“por isso os contos de fadas estão tão esquecidos!”) reforça que não há vínculo entre o papel do príncipe e o papel exercido por Quinzinho na HQ. Além do mais, o diálogo entre a HQ e os contos de fadas clássicos, estabelecendo-se relações 
dialógicas, de certa forma, dá-se pela voz de Quinzinho, já que ele as reconhece no texto.

Figura 13: Quinzinho reconhece o Gato de Botas

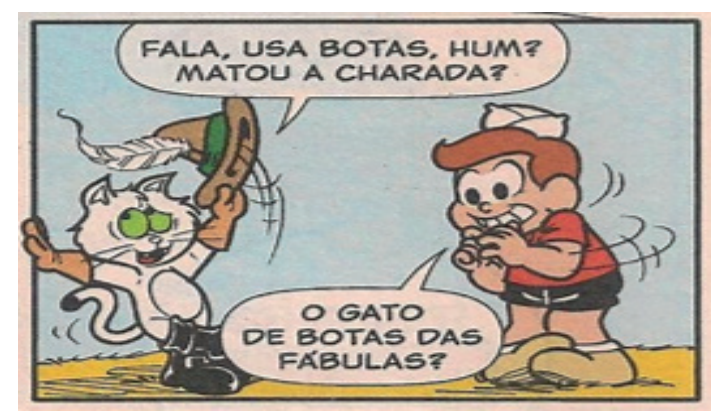

Fonte: Turma da Mônica nº 27 - Julho/2017, vinheta 5 .
Figura 14: Quinzinho reconhece o gigante da história João e o pé de feijão

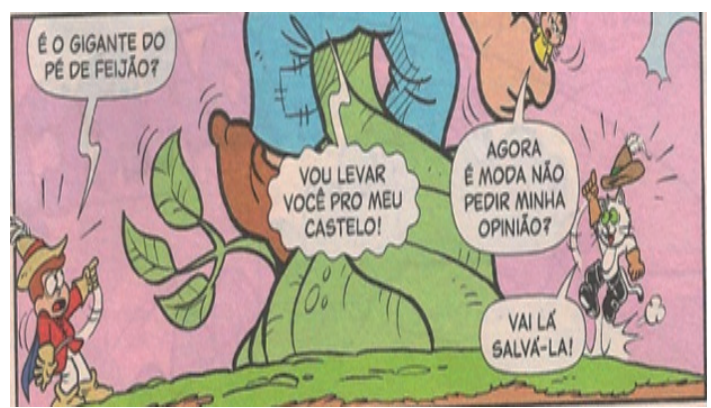

Fonte: Turma da Mônica nº 27 - Julho/2017, vinheta 18 .

É por meio de sua atitude gentil que Quinzinho consegue conquistar Magali. Ele não precisou agir como os príncipes dos contos de fadas para conquistá-la, bastou agir com gentileza para que a mulher moderna, representada por Magali, perdoasse-o por suas atitudes, consideradas estranhas por ela.

Figura 15: Quinzinho é gentil com Magali

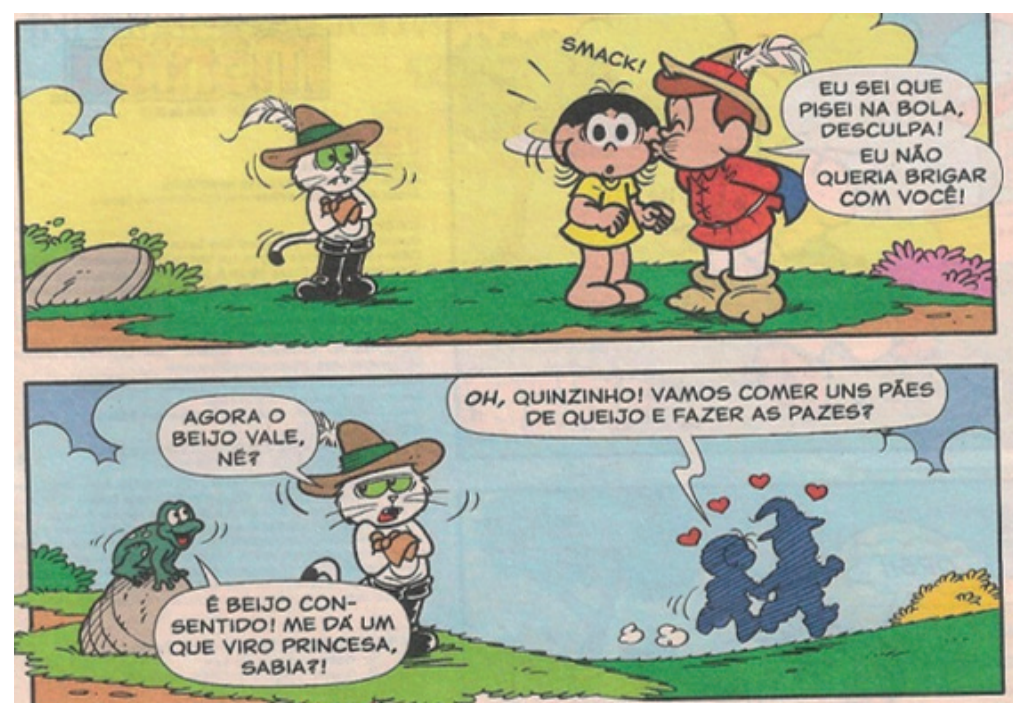

Fonte: Turma da Mônica nº 27 - Julho/2017, vinhetas 25 e 26. 
E assim, percebe-se o cruzamento das vozes na configuração de Quinzinho, já que assimila, organiza e modifica o papel exercido pelo "príncipe" nos contos de fada, os quais são destemidos, corajosos e atuam sem pensar na reação da amada.

\section{MINGAU: A VOZ DO LUDIBRIADOR E TRAVESSO}

Na HQ "Me conta qual é a desse conto", Mingau não faz o papel original de animal de estimação de Magali. Há uma reversão de seu papel, pois é um animal que fala e que se passa por o Gato de Botas dos contos de fadas. Atento aos acontecimentos ao seu redor, o personagem aparece na narrativa encostado nas linhas demarcatórias dos quadrinhos (cf. vinhetas 4,5 e 7) que estabelecem uma espécie de metalinguagem do gênero.

Figura 16: Mingau se passa por o Gato de Botas
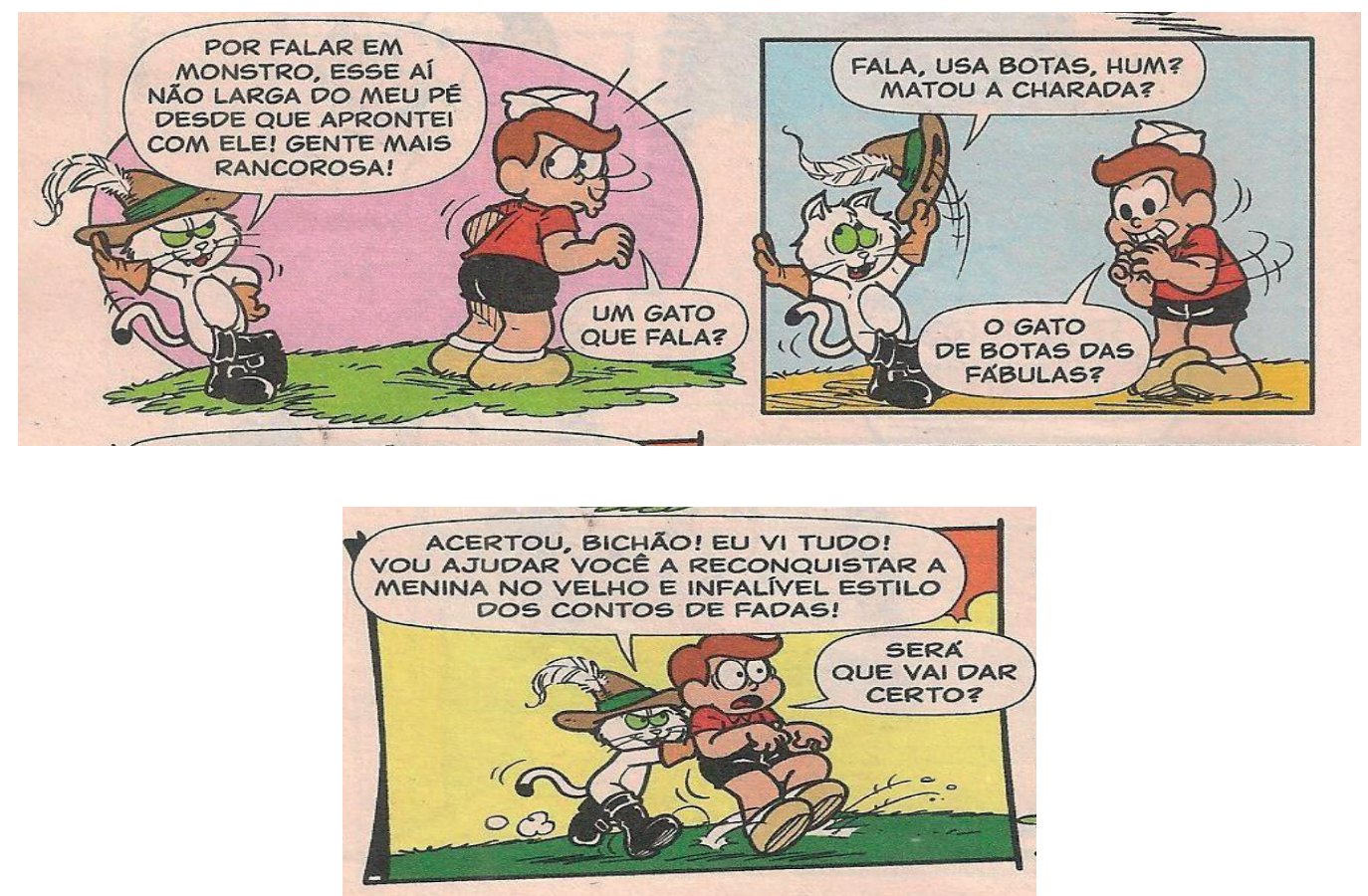

Fonte: Turma da Mônica nº 27 - Julho/2017, vinhetas 4, 5 e 6.

Por meio de mentiras e travessuras, o Gato de Botas conduz Quinzinho a reconquistar Magali no estilo dos tradicionais contos de fadas conforme mostram os quadros adiante, ou seja, enfrentando obstáculos com personagens fantásticos, tais como bruxa, gigante, dragão e ainda, com o uso de encantamentos e magias. 
Figura 17: Mingau se passa por bruxa

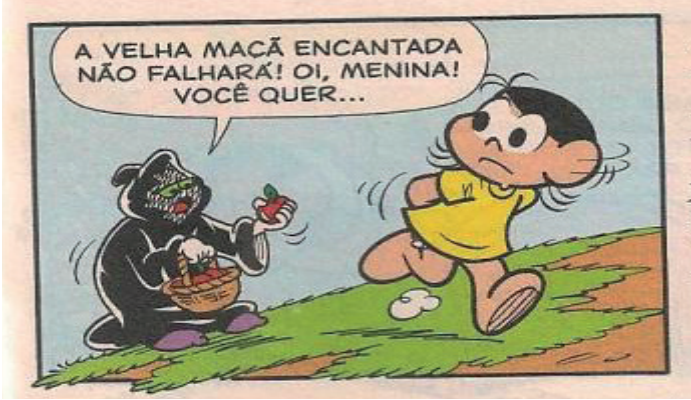

Fonte: Turma da Mônica n ${ }^{\mathrm{o}} 27$ - Julho/2017, vinheta 8 .
Figura 18: Mingau motiva Quinzinho a salvar Magali

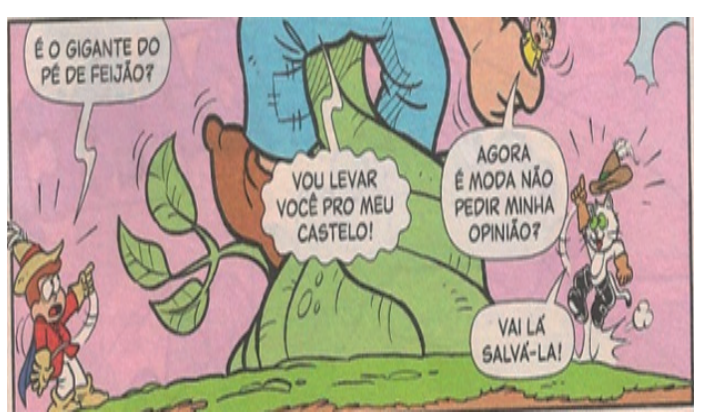

Fonte: Turma da Mônica nº 27 - Julho/2017, vinheta 18 .

É o gato quem faz ecoar na narrativa as vozes dos contos de fadas ("Fala, usa botas, hum? Matou a charada?”; “A velha maçã encantada não falhará!”; “A bela menina dorme encantada até que você, nobre menino, a desperte com um beijo de amor!"; "Pronto, agora a linda menina tá presa nessa torre!”; “Quem será que vai salvá-la e ganhar o seu amor?"). O Gato de Botas é na verdade um grande trapaceiro e ludibriador. Sempre dá um jeito de arrumar encrencas para Quinzinho reconquistar Magali. Essas representações são reforçadas no decorrer de toda a narrativa.

Figura 19: Mingau desafia Quinzinho a reconquistar Magali
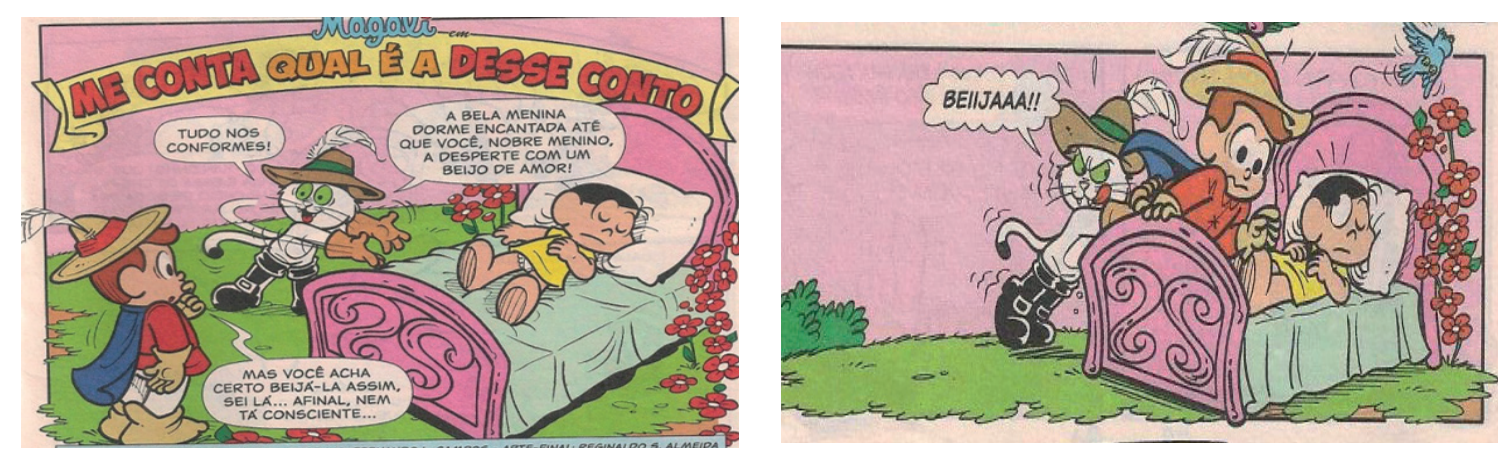


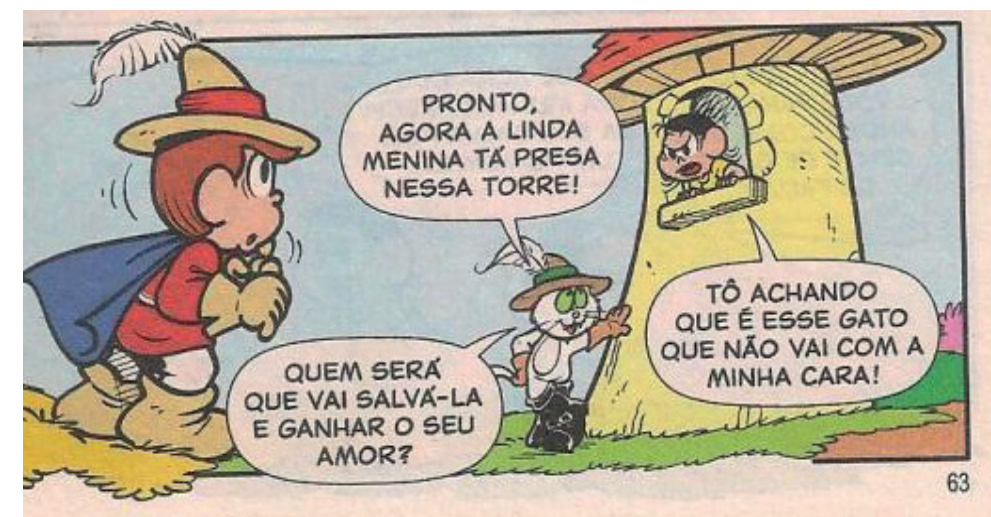

Fonte: Turma da Mônica no 27 - Julho/2017, vinhetas 12, 14 e 20.

Porém, as travessuras do Gato de Botas são todas fracassadas. Não foi por causa das astúcias do gato que Quinzinho reconquistou a namorada, mas, por sua gentileza. Desapontado, no desfecho da narrativa, o felino surge planejando novas travessuras para outros personagens.

Temos uma HQ que mantém relações dialógicas com contos de fadas clássicos da literatura infantil, adaptada aos novos contextos culturais, com uma junção de várias situações de diferentes histórias que dão mais autenticidade ao enredo. Possivelmente, as relações dialógicas estabelecidas com os contos de fadas clássicos da literatura infantil é uma forma de resgatá-los, prestar um novo sentido ao texto, causar humor e é um convite ao leitor para manter-se bem informado e atento à história, ou até mesmo, buscar saber mais sobre as enunciações que deram origem ao diálogo.

\section{QUESTÕES DE COMPREENSÃO}

No Quadro 2 adiante, apresentamos uma proposta de atividade didática para aulas de línguas na Educação Básica, destinada a alunos do Ensino Fundamental II, elaborada com base na HQ "Me conta qual é a desse conto" (cf. no anexo a versão em Português). Sugerimos respostas as questões para auxiliar o trabalho do professor. A partir da leitura da HQ, esperamos que o aprendiz acione os seus conhecimentos linguísticos e textuais, conhecimentos enciclopédicos, ative os esquemas mentais e realize inferências para construir novos saberes à narrativa.

As publicações da Turma da Mônica são interessantes recursos didáticos para serem trabalhados nas aulas de línguas. As revistas podem ser encontradas em Português, 
Inglês e Espanhol ${ }^{5}$ e são publicadas em outros países, sem haver uma modificação na caracterização dos personagens.

Quadro 2: Questões de compreensão do texto

Proposta de compreensão: Questionar os alunos sobre a HQ "Me conta qual é a desse conto".

1 - Qual é o título da HQ que você leu?

Resposta sugerida: O título da HQ é "Me conta qual é a desse conto".

2 - Quem são os autores da HQ que você leu?

Resposta sugerida: A HQ é assinada pelo cartunista Maurício de Sousa, mas na abertura da história há os nomes do roteirista Rogério Mascarenhas, o desenhista Fernando Luís Campos e arte-final de Reginaldo S. Almeida.

3 - Qual é a editora que publicou a HQ que você leu?

Resposta sugerida: A editora que publicou a HQ "Me conta qual é a desse conto" é a Editora Panini.

4 - Onde a HQ que você leu é e encontrada?

Resposta sugerida: A HQ "Me conta qual é a desse conto" é encontrada em gibi disponível para venda em revistarias, supermercados, farmácias, armazéns, livrarias, papelarias e outros estabelecimentos comerciais. A narrativa também está disponível em forma de vídeo no YouTube.

\footnotetext{
${ }^{5}$ Os nomes dos personagens da turma mudam quando são traduzidos em outras línguas. A Magali é a Maggy em inglês, Magáli em espanhol. Quinzinho é o Toddy em inglês, Boronito em Espanhol. Mingau possui o mesmo nome nesses dois idiomas, Vanilla. Mônica é Monica em inglês e Mónica em Espanhol. Cebolinha é o Jimmy Five em Inglês, Cebollita em Espanhol. Nas publicações em outros países, não há modificações nas características dos personagens. Por exemplo, para representar a dislalia de Cebolinha, no Inglês, quando o personagem fala ele usa "W" em vez de "R" (ex. BWAZIL - BRAZIL). No espanhol, quando o personagem fala, ele troca o "R" por "L" (ex. GLACIAS - GRACIAS).
} 
5 - Quais os personagens principais responsáveis pelas ações manifestadas na HQ? Descreva algumas características físicas e psicológicas compreensíveis a partir da leitura.

Resposta sugerida: Na HQ "Me conta qual é a desse conto" os personagens principais são Magali, Quinzinho e o gato Mingau que se passa por o Gato de Botas dos contos de fadas. Quinzinho é o namorado de Magali. Um menino gentil e prestativo que adora agradar a sua amada com os seus pães de queijo. Mingau é o bicho de estimação de Magali. É um gato branco, da raça angorá. Esperto, cheio de imaginação e muito travesso.

6 - Quais os personagens que colaboram com as ações realizadas pelos personagens principais?

Resposta sugerida: Na HQ "Me conta qual é a desse conto", os personagens que colaboram com as ações realizadas pelos personagens principais são os personagens dos clássicos da literatura Branca de Neve, João e o pé de feijão, Rapunzel, O Príncipe Sapo, Mônica e Cebolinha.

7 - Onde se passam os acontecimentos narrados na HQ?

Resposta sugerida: Na HQ, certamente, as cenas ocorrem no Bairro do Limoeiro, nome fictício de um bairro em São Paulo. É o local em que se passam a maioria das histórias da Turma da Mônica.

\section{8 - Quais os possíveis leitores da HQ?}

Resposta sugerida: Os possíveis leitores da HQ "Me conta qual é a desse conto" são crianças, jovens e adultos, ou seja, pessoas de todas as faixas etárias, pois as HQ da Turma da Mônica não são apenas "coisa de criança". Há uma grande quantidade de jovens e adultos que as leem.

\section{9 - Qual é o tema principal tratado na HQ?}

Resposta sugerida: O tema principal tratado na HQ "Me conta qual é a desse conto" é o desentendimento entre um casal de namorados, Magali e Quinzinho, desencadeado por causa de comida.

\section{0 - Qual o efeito humorístico causado pela HQ?}

Resposta sugerida: Na HQ o efeito humorístico está no esforço realizado por Magali para sair de tanta confusão das aventuras dos contos de fadas e voltar a ser ela mesma. 
11 - Descreva o que acontece em cada cena dos quadrinhos que compõe a HQ.

Resposta sugerida: Para responder à questão é importante considerar a seção deste artigo Análise interpretativa da HQ "Me conta qual é a desse conto".

12 - A leitura da HQ o fez lembrar de algum outro texto que dialoga com a HQ apresentada? Caso sua resposta seja positiva, indique textos que dialogam com a HQ que você conhece.

Resposta sugerida: A HQ em destaque é uma releitura dos contos de fadas O Gato de Botas, Branca de Neve, João e o pé de feijão, Rapunzel e O Príncipe Sapo.

13 - Na HQ, que sentidos são produzidos a partir do diálogo com outros textos?

Resposta sugerida: $\mathrm{Na} \mathrm{HQ}$, o diálogo com os outros textos é uma forma de resgatálos, prestar um novo sentido, causar humor e é um convite ao leitor para manter-se bem informado.

14 - Você acha que, na HQ, a personagem Magali representa uma princesa dos contos de fadas tradicionais? Por quê?

Resposta sugerida: Na HQ, a personagem Magali não representa uma princesa dos contos de fadas tradicionais, pois não possui os padrões que se esperam de uma princesa. Não é um beijo que a acorda e, sim, a própria Magali ao sentir que alguém irá beijá-la sem o seu consentimento. Não é um príncipe que a salva do castelo do gigante da história João e o pé de feijão, e, sim, ela mesma ao morder o dedo do gigante. Não é um príncipe que a salva da torre do castelo e do dragão, como ocorre em Rapunzel, mas sim, o ronco de seu estômago que faz o dragão ir para bem longe e ela escapa da prisão. Além do mais, Magali é comilona.

15 - Em sua opinião, a leitura da HQ é agradável? Caso a sua resposta seja positiva, destaque o que mais chamou a sua atenção na narrativa?

\section{Resposta pessoal.}

16 - A HQ em destaque foi publicada em português em Turma da Mônica nº 27 (julho/2017) e em outros idiomas. O gibi abriga outras HQ com temáticas diversas assinadas pelo cartunista Maurício de Sousa. Fale sobre o trabalho do cartunista a partir da HQ lida e depois pesquise as características de sua produção.

Resposta pessoal.

Fonte: A autora. 
$\mathrm{Na}$ atividade reproduzida, há perguntas de compreensão (questões 1, 2, 3, 5, 6 e 7) que apesar de ser um levantamento de informações explícitas, podem ser utilizadas para verificar se os alunos conseguiram identificar informações contextualizadoras do texto, tais como, autor, editora, características físicas e psicológicas dos personagens principais, personagens secundários, espaços em que se passa o enredo, principais acontecimentos. Porém, há questões que demandam dos alunos um nível maior de leitura (questões 9, 10, $11,13)$, busca por informações em outras fontes, e que permitem interação com o leitor ao expor opiniões (questões 4, 8, 12, 14, 15 e 16), podendo despertar nos aprendizes o interesse pela a arte e pesquisa ao envolvê-los com mais autonomia, no mundo da pesquisa.

É valido utilizar a HQ analisada nesse trabalho como objeto de estudo em sala de aula na educação básica para problematizar e repensar os papéis sociais instituídos à mulher nos contos de fadas, provocando uma pesquisa sobre os estereótipos feminino nesses enredos.

\section{CONSIDERAÇÕES FINAIS}

Ao revisar alguns pontos discutidos neste trabalho, assumimos que as análises apresentadas sobre a HQ "Me conta qual é a desse conto" têm caráter de 'incompletude', tendo em vista a complexidade que caracteriza investigar o discurso da vida e da arte. Apesar das limitações, esperamos que o trabalho possa contribuir para estudos futuros que tratem de forma mais exaustiva sobre o uso de HQ como material pedagógico promissor sobre prática de leitura no ensino de línguas em contextos de instrução.

Adiante, reproduzimos um relato de Ferrarezi Jr. (2014). O escritor rememora as aulas em seu tempo de primário, em que um de seus amigos foi rigorosamente repreendido por ter sido flagrado em sala de aula lendo os "cobiçados gibis", publicações dedicadas à circulação de HQ. Considerada por muito tempo como prejudicial e uma ameaça à juventude, as HQ eram vistas como "objetos impróprios":

(...) Aprendíamos a passar bilhetes e outros tipos de objetos impróprios dentro de sala, como os cobiçados gibis dos super-heróis, de forma a torná-los invisíveis para a professora. Certa vez, meu colega levou uma suspensão de sete dias porque foi pego com um gibi do Super-Homem dentro de sala. Uma vergonha absurda para ele! Desde aquele tempo, o Super-Homem já servia de mau exemplo para os meninos ... Dois dias depois, em plena suspensão, ele, o meu amigo, quebrou o braço. Amarrou uma toalha de banho no pescoço e tentou voar de cima da laje de sua casa. Voou, mas foi bem rápido. Aliás, o problema não foi 
o vôo, foi a aterrissagem. A professora usou isso como exemplo-domau-exemplo do gibi. Nós sabíamos que não era assim. Lembro que discutimos no recreio que, se ele estivesse na escola, não teria voado da laje nem se machucado. Hoje, penso que se a professora tivesse discutido o gibi com ele e com todos nós, e o que significa realmente ser um super-homem, nem ele teria quebrado o braço, nem muitos de nós teríamos quebrado a cara na vida. (...) (FERRAREZI JR., 2014, p. 25).

Com o passar do tempo, principalmente no final do século $\mathrm{XX}$, as restrições quanto ao uso de HQ no ambiente escolar foram atenuadas e banidas. Para concluir, acentuamos que é notório que as HQ disseminam entretenimento e informações. As narrativas combinam linguagem verbal e visual, além de remeterem a intertextos diversos, a exemplo de contos de fadas, filmes, músicas, clássicos da literatura, entre outros. Portanto, o uso desse gênero como material pedagógico em contextos de instrução é sim bastante proveitoso não só por sua ludicidade, mas por seus recursos multimodais, que facilitam e instigam à leitura, estudo dos conteúdos curriculares e à produção escrita. 


\section{REFERÊNCIAS:}

BAKHTIN, M. (VOLÓCHINOV). Marxismo e filosofia da linguagem: problemas fundamentais do método sociológico na ciência da linguagem. Tradução de Michel Lahud e Yara Frateschi Vieira. 10a edição. São Paulo: Editora HUCITEC, 2002a.

BAKHTIN, M. Estética da criação verbal. Tradução Paulo Bezerra. $4^{\mathrm{a}}$ edição. São Paulo: Martins Fontes, 2003.

BAKHTIN, M. Problemas da poética de Dostoiévski. Tradução: Paulo Bezerra. $5^{\mathrm{a}}$ edição. Rio de Janeiro: Forense Universitária, 2013.

BAKHTIN, M. Questões de literatura e de estética: a teoria do romance. Equipe de tradução: Aurora F. Bernardini; José P. Júnior; Augusto G. Júnior; Helena S. Nazário; Homero F. de Andrade. $5^{\text {a }}$ edição. São Paulo: HICITEC, 2002 b.

BARBOSA, A.; RAMOS, P.; VILELA, T.; RAMA, A.; VERGUEIRO, W. (Orgs.) Como usar as histórias em quadrinhos na sala de aula. $4^{\mathrm{a}}$ edição. São Paulo: Editora Contexto, 2016.

BRAIT, B.; PISTORI, M. H. A produtividade do conceito de gênero em Bakhtin e o Círculo. ALFA: Revista de Linguística, São Paulo, 56 (2), 2012. p. 371-401.

BRASIL. Base Nacional Comum Curricular: área de linguagens. $3^{\text {a }}$ versão revista. Brasília: MEC, 2017, p. 61-261.

BRASIL. Secretária de Educação Fundamental. Parâmetros Curriculares Nacionais: terceiro e quarto ciclos do Ensino Fundamental: Língua Estrangeira. Brasília, Ministério da Educação, 1998.

BRASIL. Senado Federal. Lei de Diretrizes e Bases da Educação Nacional: Lei $n$. 9.394/96. Brasília, 1996.

BRASIL. Tribunal de Contas da União. Avaliação do Programa Nacional Biblioteca da Escola: PNBE. Brasília, 2002.

CARVAlHO, I. M.; RIBEIRO, P. B. As HQ chegam à escola. Campinas: SP: Pontes Editores, 2018.

FERRAREZI JR., C. Pedagogia do silenciamento: a escola brasileira e o ensino de língua materna. São Paulo: Parábola Editorial, 2014. 
MACIEL, L. V. A (in)distinção entre dialogismo e intertextualidade. Linguagem em (Dis) curso - LemD, Tubarão, SC, v. 17, n. 1, p. 137 - 151, jan./abr, 2017.

MENDONÇA, M. R. Um gênero quadro a quadro: a história em quadrinhos. In: DIONISIO, A. P.; MACHADO, A. R.; BEZERRA, M. A. (Orgs.). Gêneros textuais \& ensino. Rio de Janeiro: Lucerna, 2002, p. 194-207.

MOYA, A. História da História em Quadrinhos. 2. ed. São Paulo: Editora Brasiliense, 1993.

RAMOS, P. A leitura dos quadrinhos. 2a edição. São Paulo: Editora Contexto, 2016.

ROJO, R.; BARBOSA, J. P. Hipermodernidade, multiletramentos e gêneros discursivos. São Paulo: Parábola Editorial, 2015.

SOUSA, M. A história que não está no gibi. Depoimento a Luís Colombini. Rio de Janeiro: Editora Primeira Pessoa, 2017a.

SOUSA, M. Exemplar da Mônica, número 27. São Paulo: Editora Panini, 2017.

SOUSA, M. Fascículos da coleção de miniaturas Turma da Mônica $n^{\circ} 1$ - Mônica. São Paulo: Editora Salvat, $2016 b$.

SOUSA, M. Fascículos da coleção de miniaturas Turma da Mônica $n^{\circ} 2$ - Cebolinha. São Paulo: Editora Salvat, 2016c.

SOUSA, M. Fascículos da coleção de miniaturas Turma da Mônica $n^{\circ} 4$ - Magali. São Paulo: Editora Salvat, 2016a.

SOUSA, M. Fascículos da coleção de miniaturas Turma da Mônica $n^{\circ} 32$ - Quinzinho. São Paulo: Editora Salvat, 2017b.

SOUSA, M. Fascículos da coleção de miniaturas Turma da Mônica $n^{\circ} 46$ - Mingau. São Paulo: Editora Salvat, 2017c.

SOUSA, M. Monica and friends, issue 27. São Paulo: Editora Panini, 2017.

SOUSA, M. Mónica y sus amigos, número 27. São Paulo: Editora Panini, 2017.

ZIRALDO, A. P. Uma professora maluquinha. 16 ${ }^{\text {a }}$ edição. São Paulo: Editora Melhoramentos, 2012. 


\section{ANEXO}

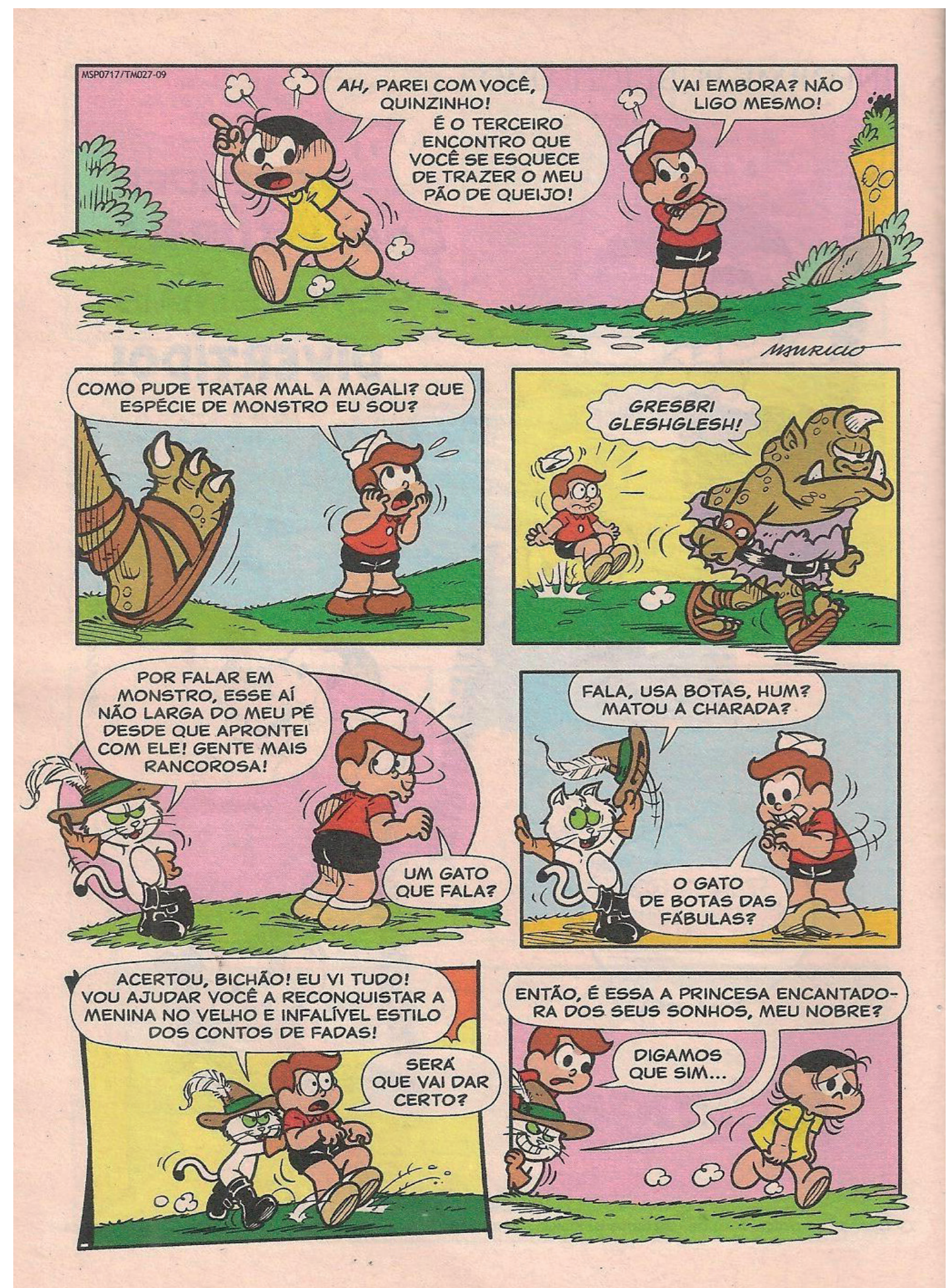



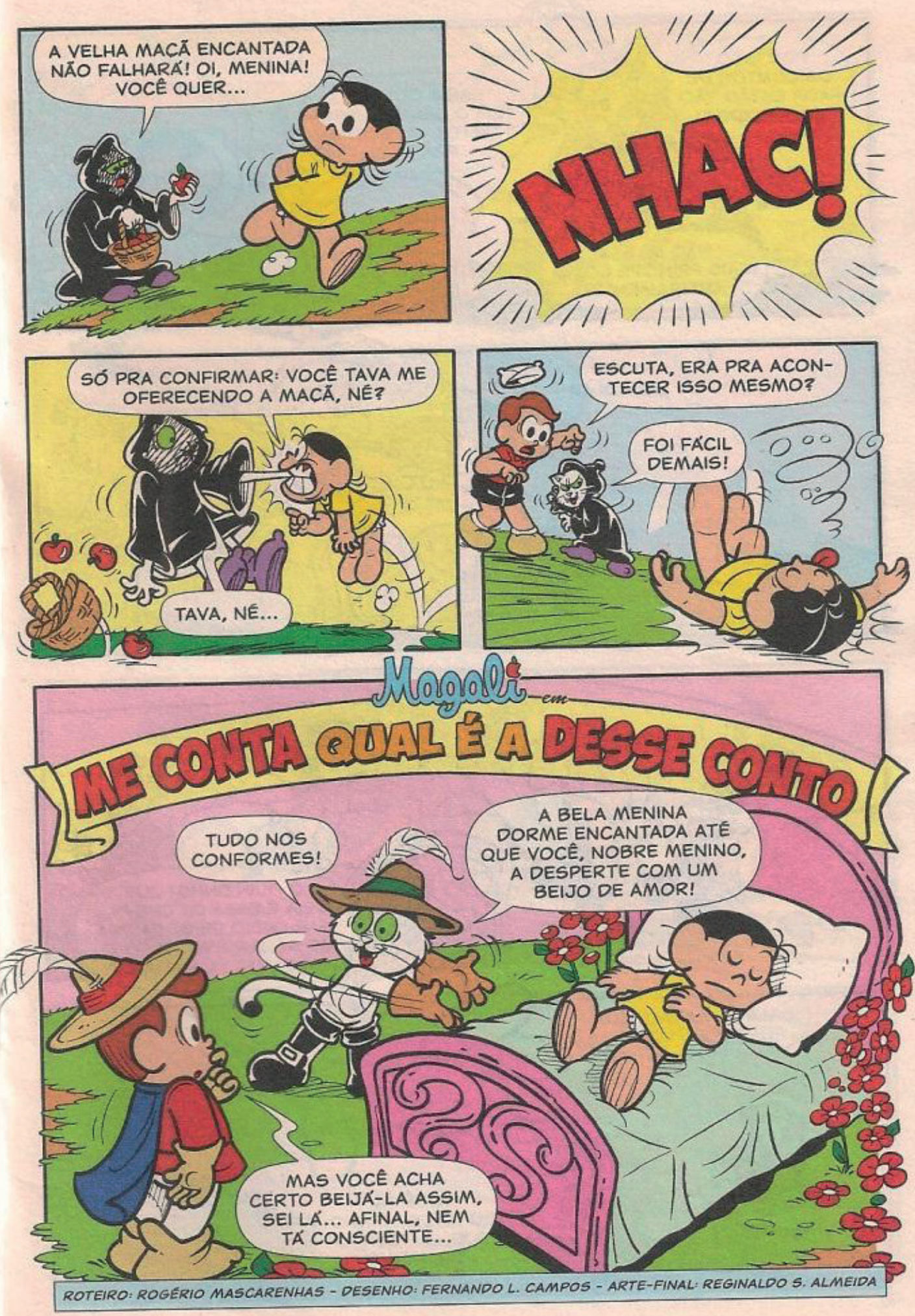


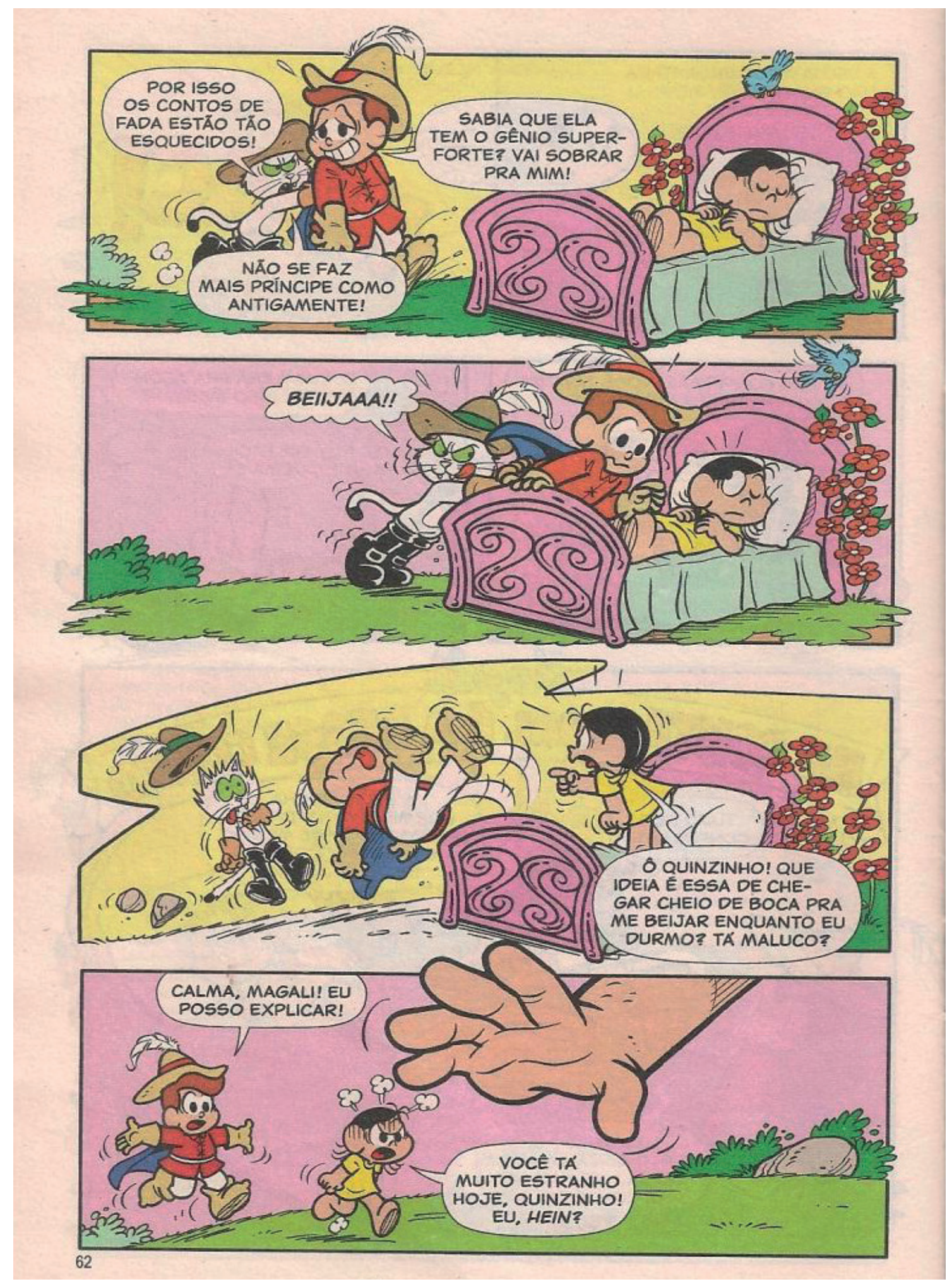




\section{REVISTA $\boldsymbol{X}$}

Universidade Federal do Paraná

Departamento de Letras Estrangeiras Modernas

ISSN: 1980-0614
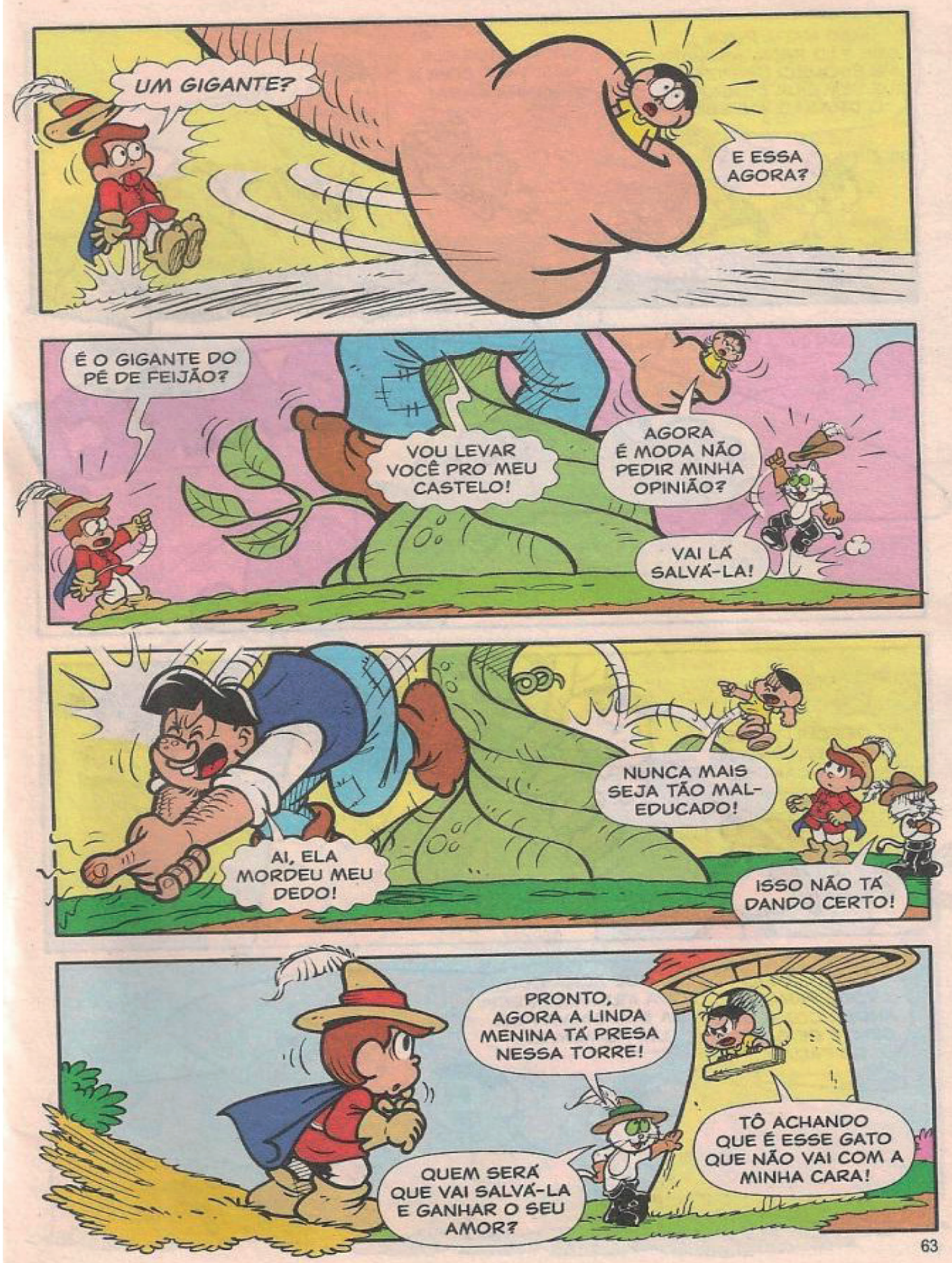

Revista X, v. 15, n. 2, p. 118-152, 2020. 


\section{REVISTA $\boldsymbol{X}$}

Universidade Federal do Paraná

Departamento de Letras Estrangeiras Modernas

ISSN: $1980-0614$

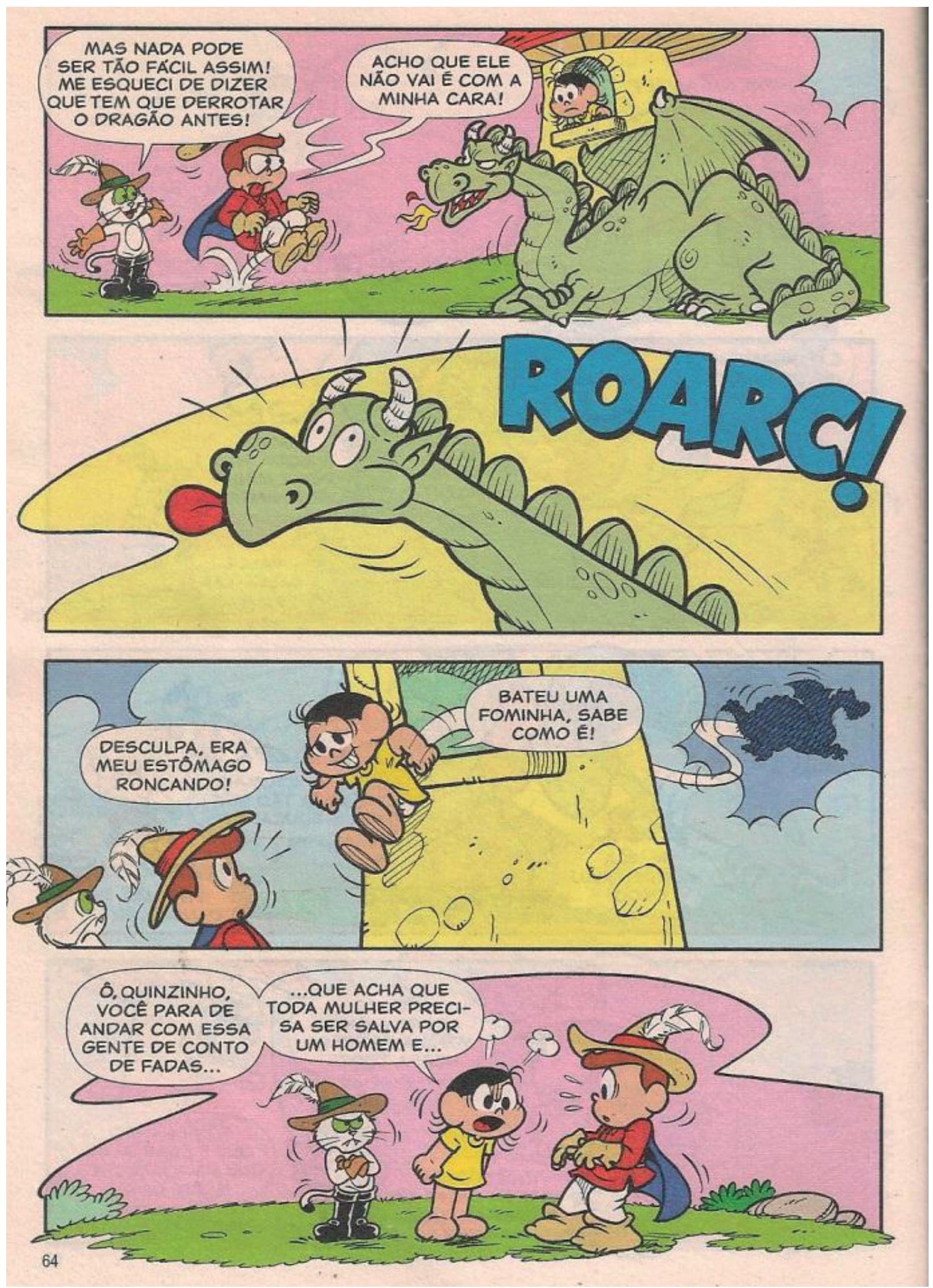

Revista X, v. 15, n. 2, p. 118-152, 2020. 


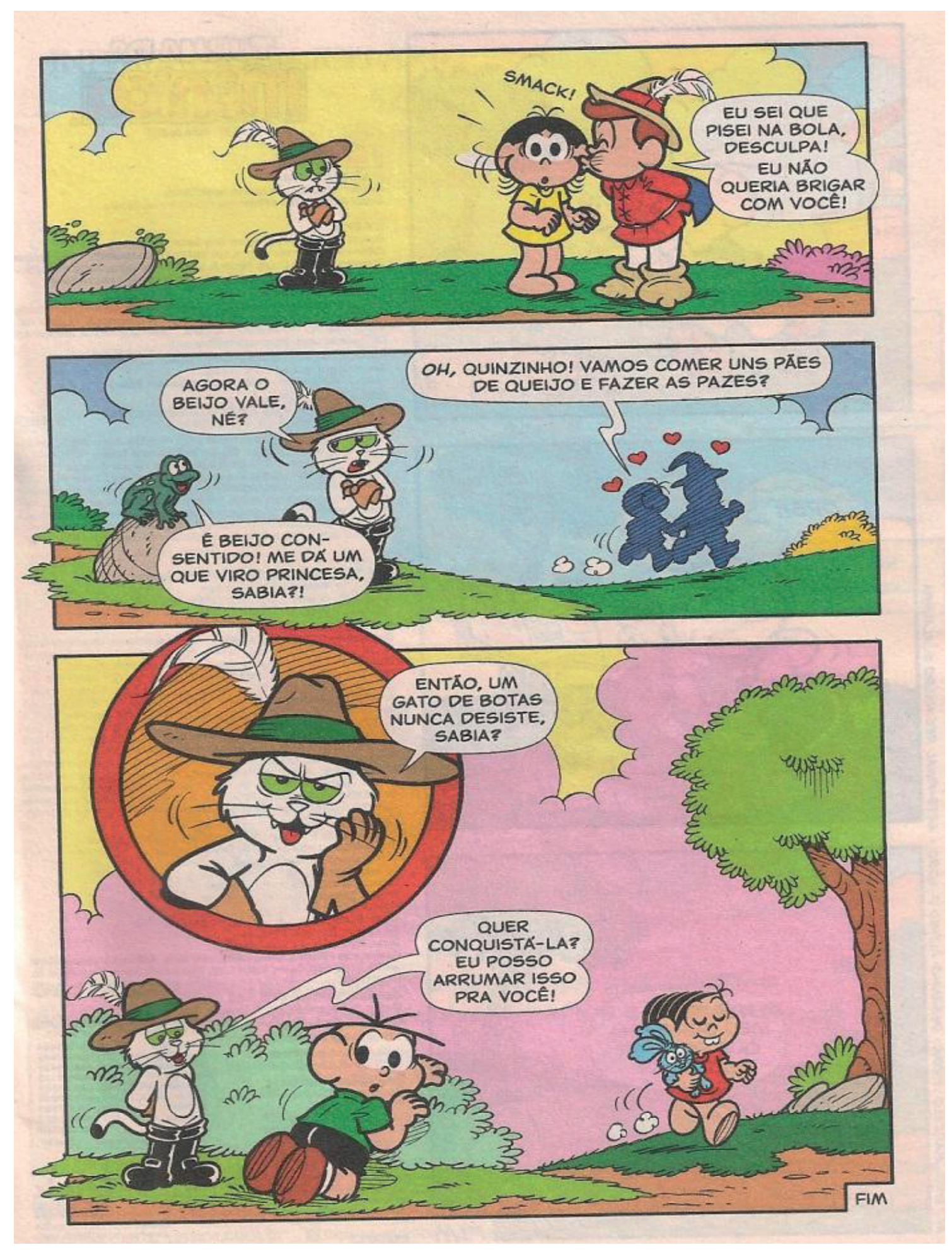

